\title{
Resolving Tiarosporella spp. allied to Botryosphaeriaceae and Phacidiaceae
}

\author{
PEDRO W. CROUS ${ }^{1,2,3}$, MICHAEL MÜLLER ${ }^{4}$, ROMINA M. SÁNCHEZ ${ }^{5}$, \\ LUCRECIA GIORDANO ${ }^{5}$, M. VIRGINIA BIANCHINOTTI ${ }^{5}$, FREDA E. \\ ANDERSON $^{5}$ \& JOHANNES Z. GROENEWALD ${ }^{1}$
}

${ }^{1}$ CBS-KNAW Fungal Biodiversity Centre, Uppsalalaan 8, 3584 CT Utrecht, The Netherlands; corresponding author e-mail:p.crous@.cbs.knaw.nl

${ }^{2}$ Forestry and Agricultural Biotechnology Institute (FABI), University of Pretoria, Pretoria 0002, South Africa

${ }^{3}$ Microbiology, Department of Biology, Utrecht University, Padualaan 8, 3584 CH Utrecht, The Netherlands

${ }^{4}$ Natural Resources Institute Finland (LUKE), P.O. Box 18, FIN-01301 Vantaa, Finland

${ }^{5}$ Centro de Recursos Naturales Renovables de la Zona Semiárida-Universidad Nacional del Sur

Camino La Carrindanga Km 7, B8000FWB, Bahía Blanca, Argentina

\begin{abstract}
The type species of the genus Tiarosporella, T. paludosa, is epitypified and confirmed as a member of the Botryosphaeriaceae. Based on morphology and DNA sequence data of the large subunit nuclear ribosomal RNA gene (LSU, 28S) and the internal transcribed spacers (ITS) and 5.8S rRNA gene of the nrDNA operon, the genus Tiarosporella is shown to be poly- and paraphyletic. A group of isolates morphologically similar to T. paludosa cluster to the Phacidiaceae (Phacidiales, Leotiomycetes) and we accommodated them in Darkera, a genus associated with needle diseases of conifers, with $D$. picea introduced as a novel taxon. This new taxon includes isolates occurring on needles of Picea spp. in Europe (Finland, Norway and Switzerland) and differs from $D$. parca according to a five-locus alignment consisting of ITS, LSU, partial 18S nuclear ribosomal RNA, translation elongation factor 1alpha and beta-tubulin genes. Four novel genera are introduced for tiarosporella-like fungi, namely Eutiarosporella based on E. tritici on Triticum aestivum from South Africa, Marasasiomyces based on M. karoo on Eriocephalus sp. from South Africa, Mucoharknessia based on M. cortaderiae on Cortaderia selloana from Argentina, and Sakireeta based on S. madreeya on Aristida setacea from India. Together with the genus Botryobambusa, these genera represent a subclade in the Botryosphaeriaceae that is ecologically diverse, occurring on Poaceae, as well as woody hosts, including endophytes, saprobes, and plant pathogens.
\end{abstract}

Keywords: coelomycetes, Dothideomycetes, ITS, LSU, Phacidiales, systematics.

Running head: TIAROSPORELLA AND ALLIED GENERA

\section{Introduction}

Several coelomycetous genera with appendaged, hyaline conidia are members of the Botryosphaeriales, namely Phyllosticta (Phyllostictaceae; Wikee et al. 2013), Melanops (Melanopsaceae; Slippers et al. 2013), Kellermania (Planistromellaceae; Minnis et al. 2012), Macrophomina (Sarr et al. 2014), Alanphillipsia, Botryobambusa, 
Botryosphaeria and Pseudofusicoccum (Botryosphaeriaceae; Crous et al. 2006, 2013, Liu et al. 2012, Phillips et al. 2013). Many other genera also belong to the Botryosphaeriales, e.g. Tiarosporella (Crous et al. 2006), but due to a lack of cultures and DNA data, these connections have largely remained unconfirmed.

A genus allied to Tiarosporella is Neottiospora, based on N. caricina (Desmazières 1843), which was introduced for coelomycetes with pycnidial conidiomata, phialidic conidiogenous cells, and hyaline, unicellular conidia with evanescent mucoid appendages (Nag Raj 1973). In a re-examination of type material by Subramanian \& Ramakrishnan (1957), they observed Neottiospora to have a conidial appendage, and considered it similar to the genus Tiarosporella, which was introduced by Von Höhnel (1919), based on T. paludosa. The appendage in Neottiospora was, however, shown to be basal by Nag Raj (1993), in contrast to the apical appendage observed in Tiarosporella. The genus Tiarospora, based on $T$. perforans, is again distinguished from these genera by having 1-septate conidia, with bipolar appendages (Nag Raj 1993). Subramanian \& Ramakrishnan (1957) also introduced the genus Sakireeta, based on S. madreeya, which has plurilocular conidiomata formed in a stroma. Furthermore, Subramanian (1961) introduced the genus Neottiosporina, based on $N$. apoda, for a pycnidial coelomycete with appendaged, 3-septate, pigmented conidia. In their treatment of the genus, Sutton \& Alcorn (1974) considered conidia of $N$. apoda to be hyaline, and thus also described $N$. masonii in the genus. Nag Raj (1993) did not consider conidial pigmentation of paramount importance in this genus, and hence also allocated several species with hyaline conidia to it, the unifying factor being that the conidia were septate, unlike the aseptate conidia of Tiarosporella.

Species of Tiarosporella have traditionally been associated with members of Poaceae (Sutton \& Marasas 1976, Nag Raj 1993), although recent studies have also reported them from woody hosts (Jami et al. 2012, 2014). Not much is known about the pathogenicity of these fungi, but several species of Tiarosporella have been associated with needle diseases of conifers, either as pathogens or endophytes (Sieber 1988, Karadžić 1998, Müller \& Hantula 1998), some of which have been linked to sexual morphs in Darkera in Phacidiaceae (Phacidiales, Leotiomycetes) (Whitney et al. 1975, DiCosmo et al. 1984). Species of Phacidium s.str. (Phacidiaceae) have been shown to cluster with Ceuthospora asexual morphs, which also have hyaline conidia with apical mucoid appendages (Crous et al. 2014). The relation of Tiarosporella species included in the Botryosphaeriaceae, to other similar morphs included in the Phacidiaceae has so far remained unclear. The aim of the present study was thus to resolve the generic relationships of this complex as far as possible, and delineate those genera for which cultures could be obtained.

\section{Materials and Methods}

\section{Isolates}

Tissue samples showing conidiomata were placed in moist chambers to enhance sporulation. Single conidial colonies were grown in Petri dishes containing $2 \%$ malt extract agar (MEA) as described earlier (Crous et al. 1991). Colonies were subcultured onto potato-dextrose agar (PDA), oatmeal agar (OA), MEA (Crous et al. 2009b), and pine needle agar (PNA) (Smith et al. 1996), and incubated at $25^{\circ} \mathrm{C}$ under continuous near-ultraviolet light to promote sporulation. Reference strains were 
deposited at the CBS-KNAW Fungal Biodiversity Centre in Utrecht, Netherlands (CBS).

DNA isolation, amplification and analyses

Genomic DNA was extracted from fungal colonies growing on MEA using the UltraClean ${ }^{\mathrm{TM}}$ Microbial DNA Isolation Kit (MoBio Laboratories, Inc., Solana Beach, CA, USA) following the manufacturer's protocols. Part of the nuclear rDNA operon spanning the 3' end of the 18S nrRNA gene, both internal transcribed spacer regions, the 5.8S nrRNA gene, and the fist approximately 950 nucleotides of the 5 ' end of the 28S nrRNA gene (ITS) was amplified using the primers V9G (de Hoog \& Gerrits van den Ende 1998) and LR5 (Vilgalys \& Hester 1990). The primers ITS4 (White et al. 1990) and LSU1Fd (Crous et al. 2009a) were used as internal sequence primers to provide sequences of high quality over the entire length of the amplicon. Part of the 5 , end of the 18S nrRNA gene was amplified and sequenced with the primers NS1 and NS4 (White et al. 1990), part of the translation elongation factor 1-alpha gene (TEF) with the primers EF1-728F (Carbone \& Kohn 1999) and EF-2 (O'Donnell et al. 1998) and part of the beta-tubulin gene using primers TUB3Fd and TUB4Rd (Groenewald et al. 2013) or Bt-2a and Bt-2b (Glass \& Donaldson 1995). The sequence alignment and subsequent phylogenetic analyses were carried out using methods described by Lombard et al. (2011); gaps were treated as "fifth state" data. The alignment for the Botryosphaeriaceae is based on the dataset used by Phillips et al. (2013). Sequences derived in this study were lodged in GenBank (Table 1) and the alignments in TreeBASE (www.treebase.org/treebase/index.html).

\section{Morphology}

Observations were made with a Zeiss V20 Discovery stereo-microscope, and with a Zeiss Axio Imager 2 light microscope using differential interference contrast (DIC) illumination and an AxioCam MRc5 camera and software. Measurements and photographs were made from structures mounted in clear lactic acid. The $95 \%$ confidence intervals were derived from 30 observations ( $\times 1000$ magnification), with the extremes given in parentheses. Ranges of the dimensions of other characters are given. Colony colours (surface and reverse) were established using the colour charts of Rayner (1970). Recently collected sections of leaves bearing fruiting bodies of the fungus were pressed, and preserved in the Herbarium of the Biology Department, Universidad Nacional del Sur (BBB), or at the CBS in Utrecht, and taxonomic novelties were deposited in MycoBank (Crous et al. 2004).

\section{Results}

\section{Phylogeny}

Three phylogenies were generated; the first was based on 56 LSU sequences (including the outgroup Dothidea sambuci GenBank AY544681) and was used to determine the familial and ordinal relationships of the studied species (Fig. 1), the second was based on a combined ITS and LSU alignment of 44 isolates (including the outgroup Saccharata proteae strain CBS 115206) and was used to determine the genus relationships and species identification within the Botryosphaeriaceae (Fig. 2), and the third was based on a combined ITS, LSU, SSU, TEF and TUB alignment of 18 Darkera isolates and was used for species identification (Fig. 3).

The first analysis (LSU) (including the outgroup sequence) and the resulting dataset of 773 characters, including alignment gaps which were treated as fifth base, 


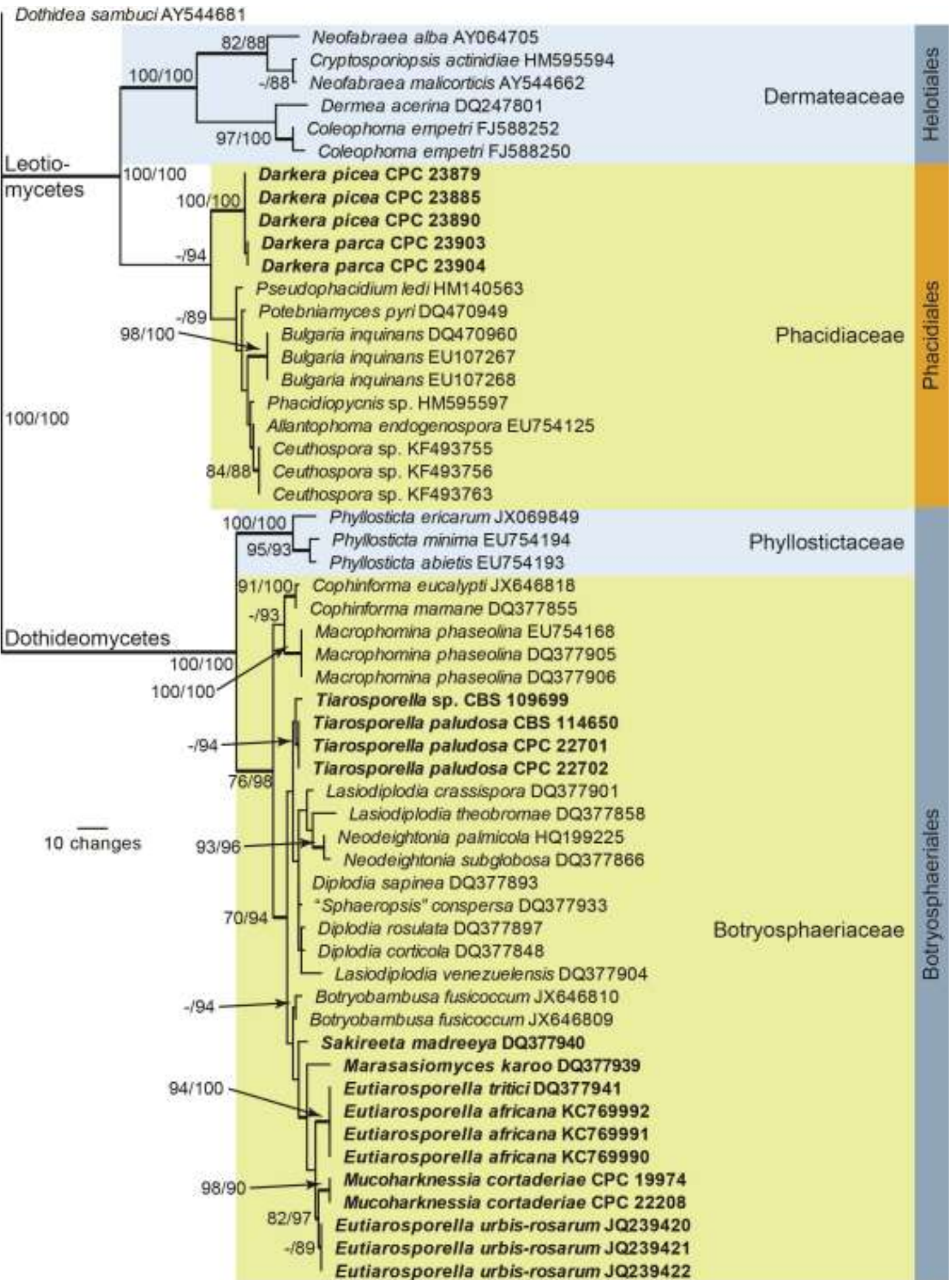

FIGURE 1. The first of 1000 equally most parsimonious trees $(\mathrm{TL}=367 ; \mathrm{CI}=0.638 ; \mathrm{RI}=0.928 ; \mathrm{RC}$ $=0.591)$ resulting from a parsimony analysis of the LSU (28S) sequence alignment. The bootstrap support values are indicated at the nodes (parsimony bootstrap / distance with HKY85 model bootstrap; only values $>74 \%$ ) and the scale bar represents the number of changes. Thickened branches reflect those branches present in the strict consensus tree. Orders are indicated in darker blue and orange blocks and family names in light blue and light brown blocks. Species names of interest to this study are shown in bold text. The tree was rooted to Dothidea sambuci (GenBank AY544691). 


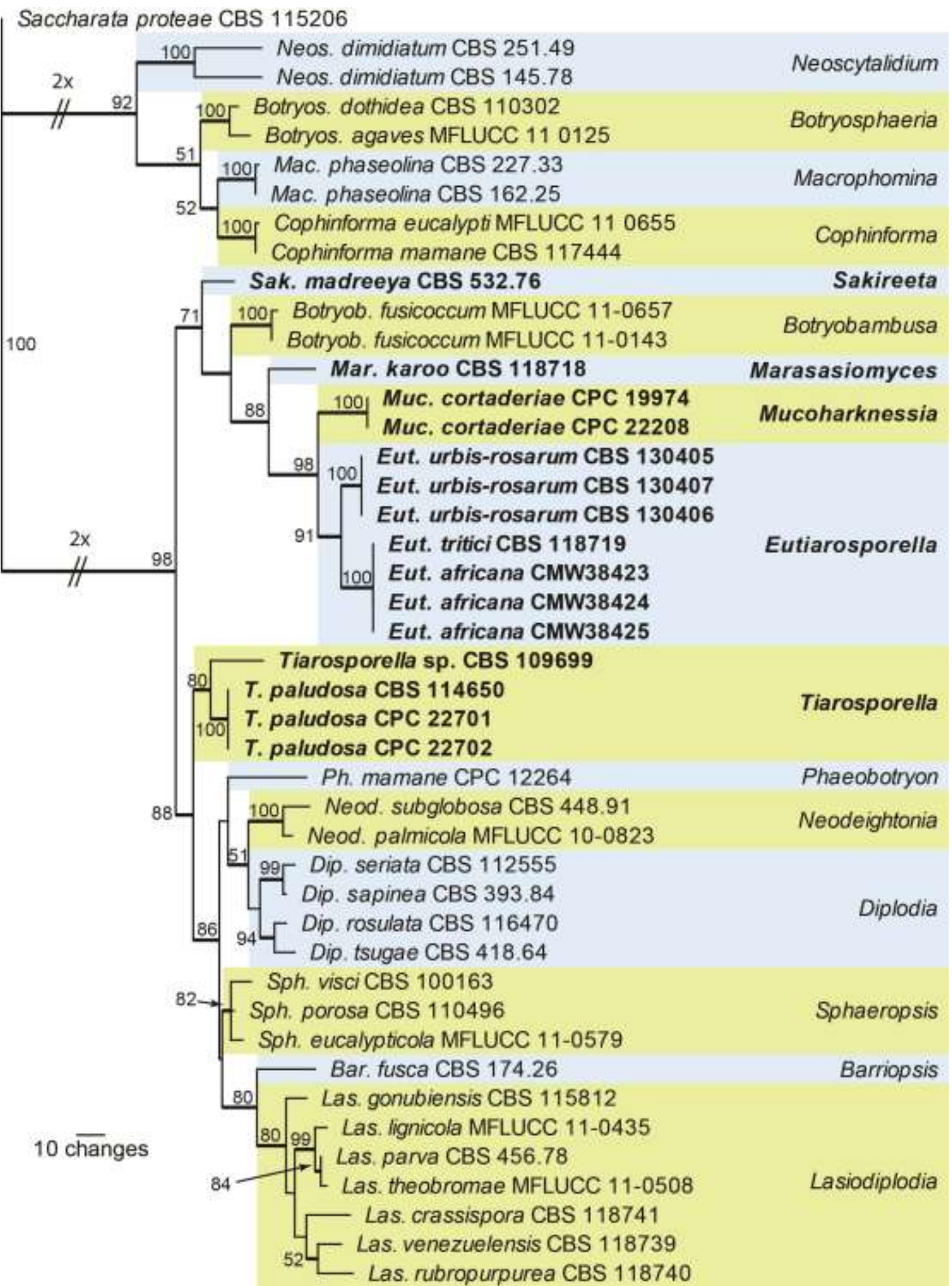

FIGURE 2. The first of 22 equally most parsimonious trees $(\mathrm{TL}=619 ; \mathrm{CI}=0.577 ; \mathrm{RI}=0.809 ; \mathrm{RC}=$ 0.467 ) resulting from a parsimony analysis of the combined ITS and LSU alignment representing genera in the Botryosphaeriaceae. The bootstrap support values are indicated at the nodes and the scale bar represents the number of changes. Thickened branches reflect those branches present in the strict consensus tree. Genus names in light blue and light brown blocks and abbreviated genus names used for the species follow from the genus name used for the corresponding clade. Species names of interest to this study are shown in bold text. The tree was rooted to Saccharata proteae (strain CBS 115206; ITS GenBank KF531812, LSU GenBank KF531812). 
consisted of 604 constant characters, 36 variable parsimony-uninformative characters and 133 parsimony-informative characters. The maximum of 1000 equally most parsimonious trees were retained $(\mathrm{TL}=367 ; \mathrm{CI}=0.638 ; \mathrm{RI}=0.928 ; \mathrm{RC}=0.591)$, the first of which is presented in Fig. 1. The overall topology was identical between the distance tree (data not shown) and the presented parsimony tree (Fig. 1) with some minor rearrangements of terminal clades in the different families. Overall, the parsimony analysis yielded less well-supported nodes compared to the distance analysis. The Dermateaceae was well-supported in both analyses, whereas the Phacidiaceae was only supported in the distance analysis. The Darkera clade itself is well-supported in both analyses, although the deeper structure of the sub-clades of the Phacidiaceae collapses into a basal polytomy in the parsimony analysis (see strict consensus branches in Fig. 1). The Phyllostictaceae is well-supported in both analyses, whereas the Botryosphaeriaceae is strongly supported in the distance analysis (98\% bootstrap support) but less so in the parsimony analysis (76\% bootstrap support). The LSU phylogeny based on the current dataset alone does not provide a wellsupported topology for the Botryosphaeriaceae and therefore the data was combined with ITS for the second analysis.

The second analysis (combined ITS and LSU alignment) (including the outgroup sequence) and the resulting dataset of 1243 characters, including alignment gaps which were treated as fifth base, consisted of 976 constant characters, 92 variable parsimony-uninformative characters and 175 parsimony-informative characters. Twenty-two equally most parsimonious trees were obtained (TL $=619$; CI $=0.577 ; \mathrm{RI}=0.809 ; \mathrm{RC}=0.467)$, the first of which is presented in Fig. 2. In this phylogeny, all genera that are presented by more than one strain or species are supported with a parsimony bootstrap support value of at least $80 \%$; the only exception is Diplodia which is split into two lineages without support for the connecting node. The tiarosporella-like strains are polyphyletic in the tree and therefore novel genera are introduced below to accommodate those not clustering in the Tiarosporella clade. Except for Tiarosporella tritici (=Eutiarosporella tritici, see below) and T. africana (=Eut.

africana, see below), all species in the ITS-LSU phylogeny could be resolved. In the case of this exception, the two species can easily be distinguished based on their TEF or TUB sequences (data not shown).

The third analysis (combined ITS, LSU, SSU, TEF and TUB alignment) was based on the resulting dataset of 2879 characters, including alignment gaps which were treated as fifth base, consisted of 2857 constant characters, 3 variable parsimony-uninformative characters and 19 parsimony-informative characters ( $\mathrm{TL}=$ $22 ; \mathrm{CI}=1.0 ; \mathrm{RI}=1.0 ; \mathrm{RC}=1.0$ ). Only a single most parsimonious tree was obtained, presented in Fig. 3, which clearly separated the strains belonging to Darkera picea from those belonging to $D$. parca.

\section{Taxonomy}

Higher order classification:- Leotiomycetes, Phacidiales, Phacidiaceae

Darkera H.S. Whitney, J. Reid \& Piroz., Canadian Journal of Botany 53: 3052 (1975) 


\section{D. parca}

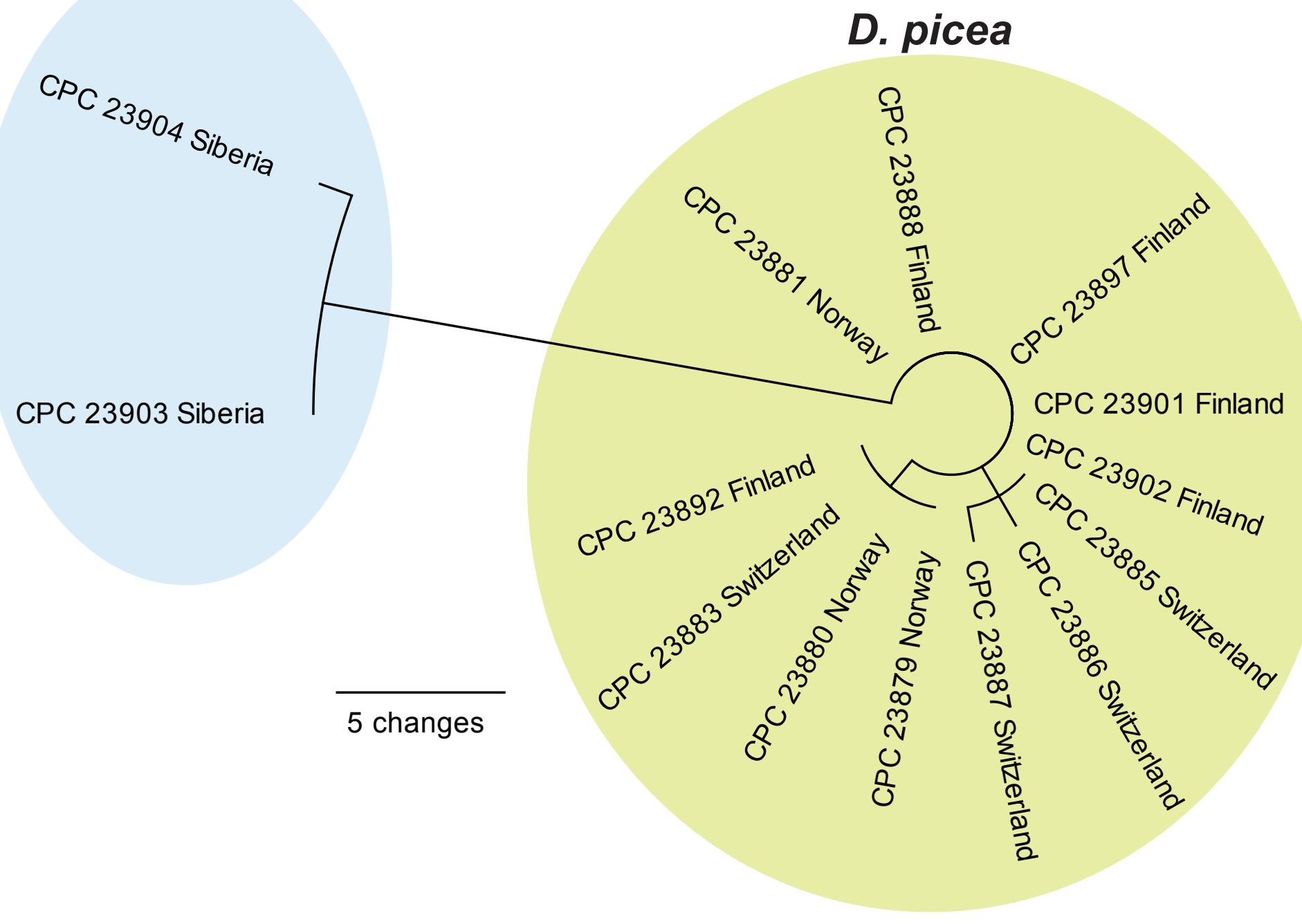

FIGURE 3. The single most parsimonious circle tree $(\mathrm{TL}=22 ; \mathrm{CI}=1.0 ; \mathrm{RI}=1.0 ; \mathrm{RC}=1.0)$ resulting from an unrooted parsimony analysis of the combined ITS, LSU, SSU, TEF and TUB alignment strains of Darkera. Host countries are shown next to the culture accession number. The scale bar represents the number of changes. 
Foliicolous. Ascomata amphigenous, scattered to aggregated, black, confluent to elongate-ellipsoid, immersed, subhypodermal, opening by longitudinal rupture, upper layer of dark textura epidermoidea; subhymenium of pale brown pseudoparenchymatal cells, forming a textura angularis. Paraphyses simple to branched, septate, slightly swollen at apex, smooth, frequently invested in mucilage. Asci clavate, 8-spored, apex slightly flattened, staining positive in Meltzer's reagent. Ascospores biseriate, ellipsoid to subreniform, aseptate, guttulate, hyaline, becoming pale brown. Conidiomata globose, immersed to erumpent, brown, opening by means of an irregular rupture; wall of 3-6 layers of brown textura angularis. Conidiophores reduced to conidiogenous cells. Conidiogenous cells lining the inner cavity, hyaline, smooth, ampulliform to subcylindrical, proliferating percurrently at apex, mono- to polyphialidic. Paraphyses intermingled among conidiogenous cells, hyaline to pale brown, smooth to verruculose, septate, subcylindrical with obtuse ends. Conidia solitary, hyaline, smooth, guttulate, subcylindrical to fusoid-ellipsoid, straight to curved, apex apiculate, tapering at base to truncate hilum; apex with flared mucoid appendage.

Type species:- Darkera parca H.S. Whitney, J. Reid \& Piroz.

Darkera abietis H.S. Whitney, J. Reid \& Piroz., Canadian Journal of Botany 53: 3052 (1975)

Synonym: Tiarosporella abietis H.S. Whitney, J. Reid \& Piroz., Canadian Journal of Botany 53: 3055 (1975)

Note:- This taxon is known to occur on Abies spp., with conidia being (29-)36-42 $\times$ (7.5-)8-9 $\mu \mathrm{m}$ (Karadžić 1998). A detailed description and illustration is provided by Nag Raj (1993). Because T. abietis is not congeneric with the genus Tiarosporella, we propose to use the name of the sexual morph, Darkera, for D. abietis and other taxa congeneric with it (Whitney et al. 1975). The asexual morph of Darkera resembles species of Phacidium (= Ceuthospora, Crous et al. 2014), but the latter tends to have multilocular conidiomata with several semi-papillate ostioles, smaller conidia and branched conidiophores. Species of Darkera are endophytic, and possibly weakly pathogenic on conifers (Müller \& Hantula, 1998).

\section{Darkera durmitorensis (Karadžić) Crous, comb. nov. MycoBank MB811245}

Basionym: Tiarosporella durmitorensis Karadžić, European Journal of Forest Pathology 28: 148 (1998)

Note:- This taxon is known to occur on Abies spp., with conidia being 33-60 × 9.5$13.5 \mu \mathrm{m}$ (Karadžić 1998). Based on its morphology (large unilocular conidiomata and long, wide conidia) and ecology (occurring on Picea spp.), its clearly a species of Darkera, and not Tiarosporella, and hence a new combination is proposed for it.

Darkera parca H.S. Whitney, J. Reid \& Piroz., Canadian Journal of Botany 53: 3053 (1975); Fig. 4 

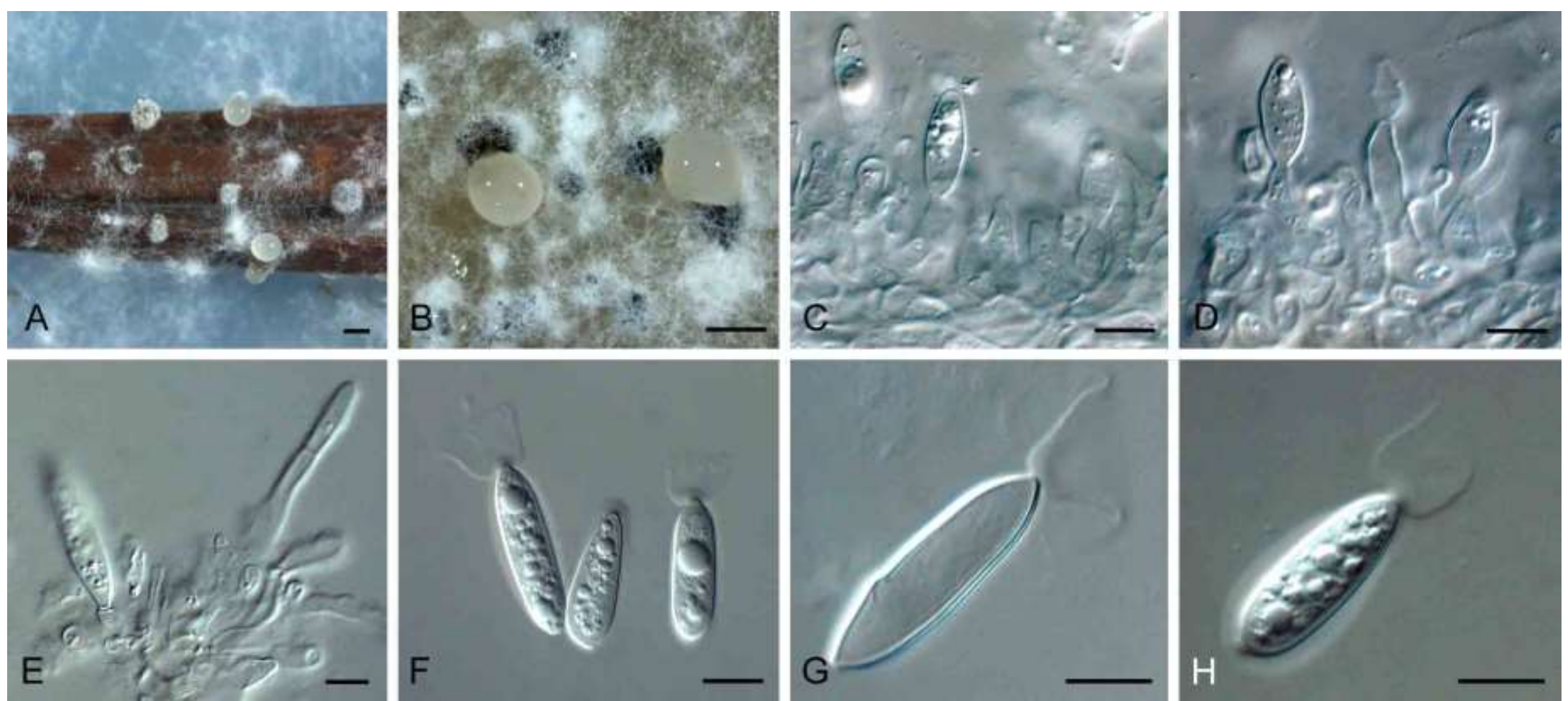

FIGURE 4. Darkera parca (CPC 23904). A. Conidiomata on PNA. B. Conidiomata on OA. C-E. Conidiogenous cells. F-H. Conidia. Scale bars: A $=250 \mu \mathrm{m}$, all others $=$ $10 \mu \mathrm{m}$. 
Synonyms: Sphaeropsis parca Berk. \& Broome, Annals and Magazine of Natural History 5: 420 (1850)

Phoma parca (Berk. \& Broome) Sacc., Sylloge fungorum (Abellini) 3: 100 (1884)

Macrophoma parca (Berk. \& Broome) Berl. \& Voglino, Atti della Società VenezianaTrentina-Istriana di Scienze Naturali 10: 191 (1886)

Sirococcus parcus (Berk. \& Broome) M. Morelet, as "parca”, Bulletin de la Société des Sciences Naturelles et d'Archéologie de Toulon et du Var 205: 9 (1973)

Tiarosporella parca (Berk. \& Broome) H.S. Whitney, J. Reid \& Piroz., Canadian Journal of Botany 53: 3055 (1975)

Conidiomata globose, immersed to erumpent, brown, up to $250 \mu \mathrm{m}$ diam, opening by means if an irregular rupture; wall of 3-6 layers of brown textura angularis.

Conidiophores reduced to conidiogenous cells. Conidiogenous cells lining the inner cavity, hyaline, smooth, ampulliform to subcylindrical, proliferating percurrently at apex, mono- to polyphialidic, $8-15 \times 3-4 \mu \mathrm{m}$. Paraphyses intermingled among conidiogenous cells, hyaline to pale brown, smooth to verruculose, $0-4$-septate, subcylindrical with obtuse ends, 30-55 × 2-3 $\mu \mathrm{m}$. Conidia solitary, hyaline, smooth, guttulate, fusoid-ellipsoid to subcylindrical, straight to curved, apex apiculate, tapering at base to truncate hilum, $2 \mu \mathrm{m}$ diam, $(22-) 25-30(-41) \times(6-) 7(-7.5) \mu \mathrm{m}$; apex with flared mucoid appendage, up to $15 \mu \mathrm{m}$ long, $13 \mu \mathrm{m}$ diam (based on CPC 23904).

Culture characteristics:- Colonies dirty white on all media, with moderate aerial mycelium and feathery margins, covering dish in 1 mo.

Specimens examined:- SIBERIA. Buriatia, Zum Murino, Tunkinski-valley, on needles of $P$. abies, 14 Nov. 2008, M. Müller, Ir 406 = CPC 23903; roadside between Zum Murino and Irkutsk, healthy needles of needles of $P$. abies var. obovata, 14 Nov. 2008, M. Müller, Ir $419=$ CPC 23904.

Notes:- Although the connection between the sexual and asexual morph was based on association, and not confirmed via culture studies, we regard this link as probably correct, as tiarosporella-like morphs have been linked to more than one species of Darkera (Whitney et al. 1975). Furthermore, the present fungus corresponds very well with the asexual morph identified by Whitney et al. (1975) from Canada as $T$. parca (conidia (20-)23-40 × 4-6(-7) $\mu \mathrm{m}$ ), and linked to Darkera parca. However these dimensions differ slightly from those provided later by Nag Raj (1993) for $D$. parca, which are larger, (29-)35-43 × 9-12 $\mu \mathrm{m}$. It could well be that the original species described from the UK as Sphaeropsis parca Berk. \& Broome is not conspecific with the Canadian D. parca. For this reason we propose to retain the name D. parca H.S. Whitney, J. Reid \& Piroz. 1975 for the collections from Canada and Siberia. Further cultures and molecular data need to be studied to resolve the issue if Darkera parca from Canada is conspecific with Sphaeropsis parca Berk. \& Broome 1850 from the UK.

Darkera picea Crous \& M.M. Müller, sp. nov. MycoBank MB811246; Fig. 5

Etymology:- Named after the host genus from which it was collected, Picea.

Conidiomata globose, immersed to erumpent, brown, up to $250 \mu \mathrm{m}$ diam, opening by means of an irregular rupture; wall of 3-6 layers of brown textura angularis.

Conidiophores reduced to conidiogenous cells. Conidiogenous cells lining the inner 

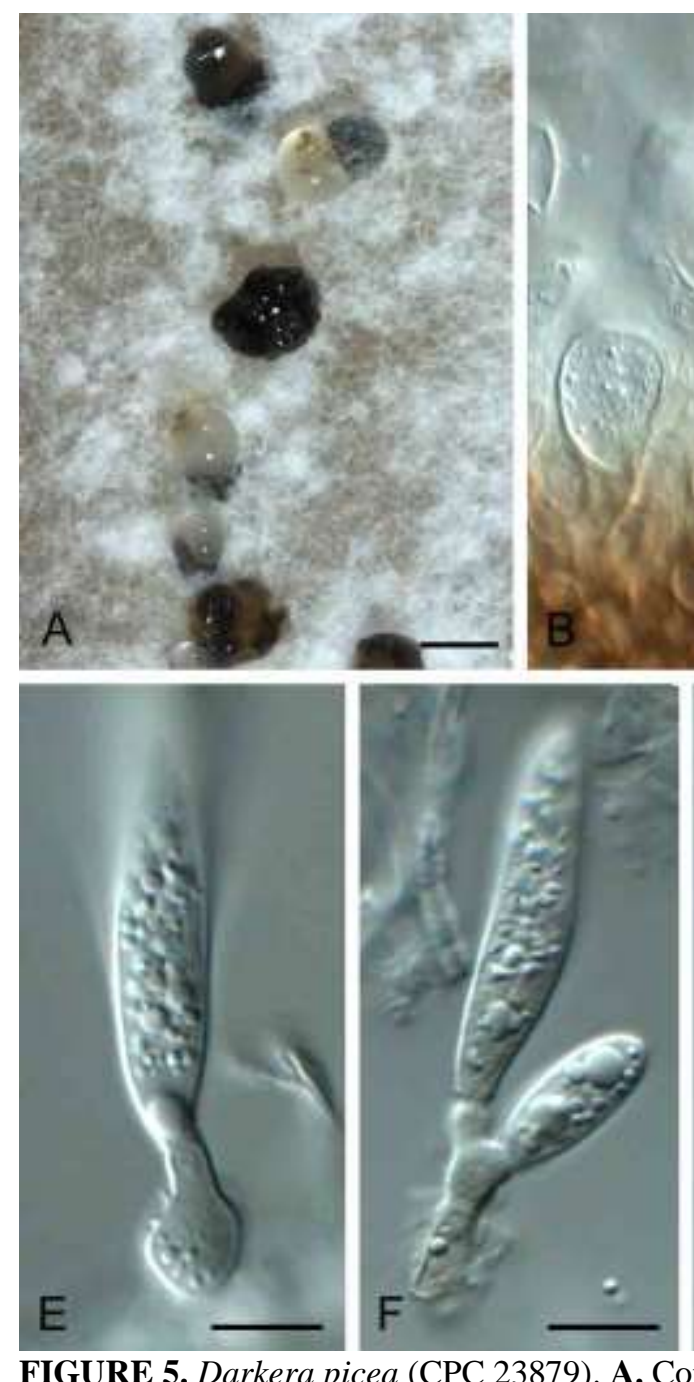

FIGURE 5. Darkera picea (CPC 23879). A. Conid

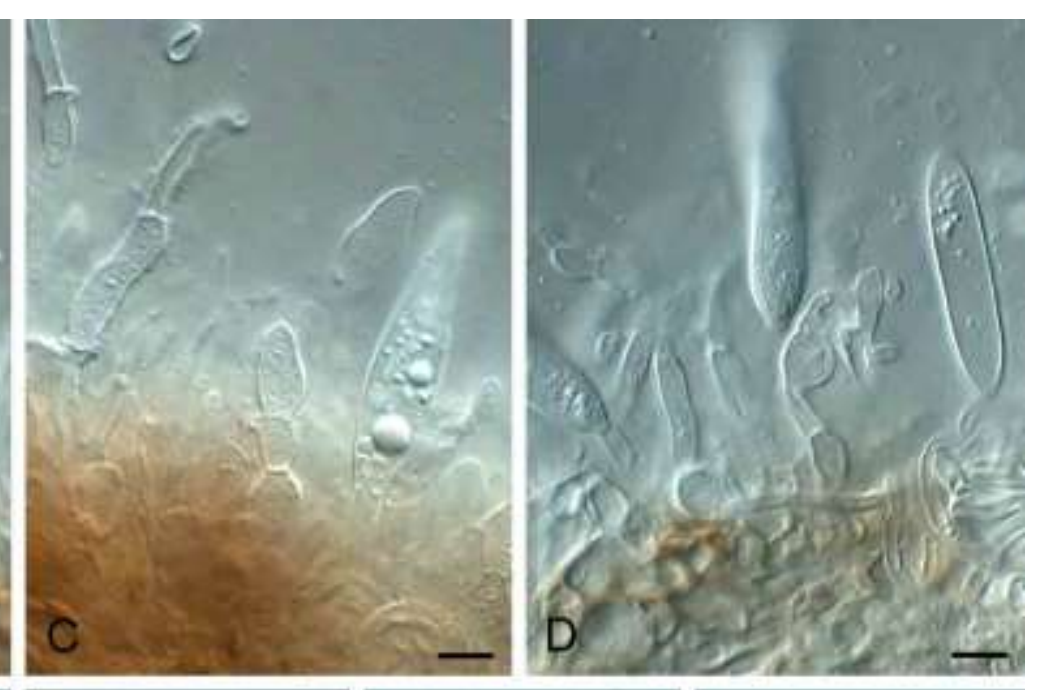

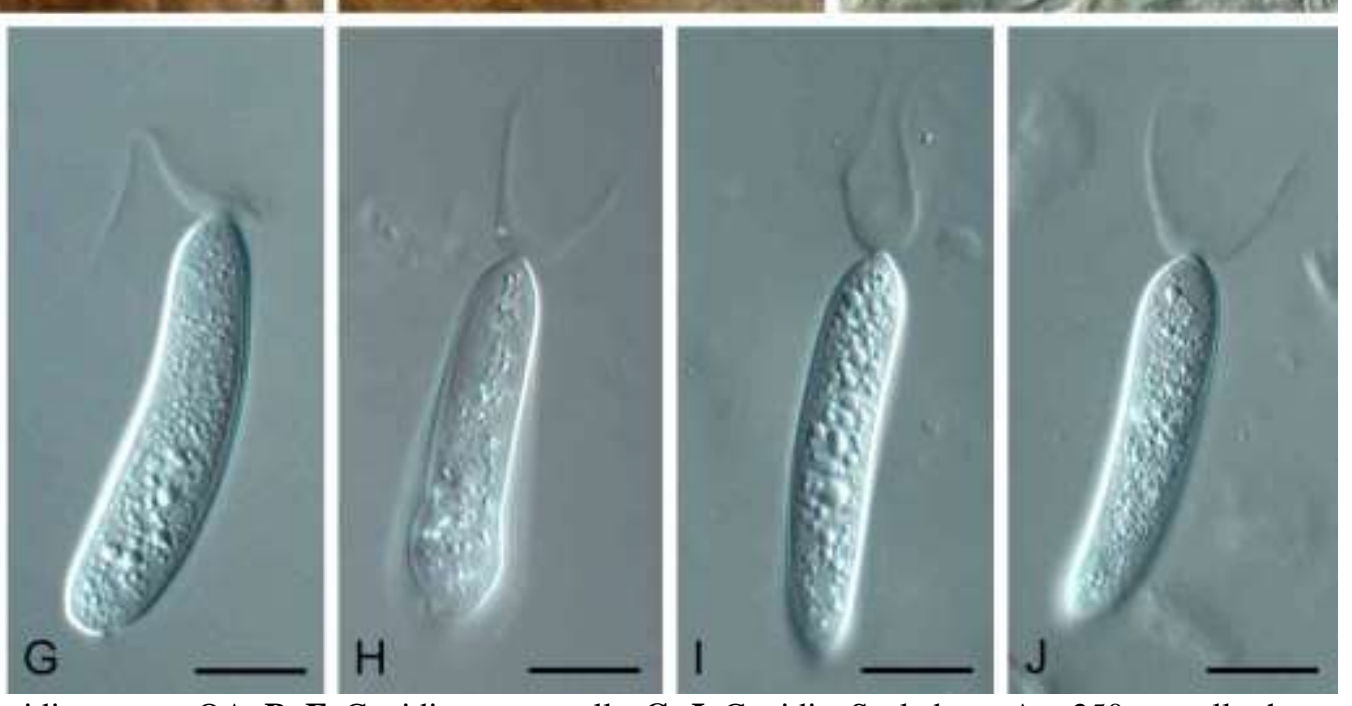

onidiomata on OA. B-F. Conidiogenous cells. G-J. Conidia. Scale bars: A $=250 \mu \mathrm{m}$, all others $=10 \mu \mathrm{m}$. 
cavity, hyaline, smooth, ampulliform to subcylindrical, proliferating percurrently at apex, mono- to polyphialidic, 5-20 $\times 4-5 \mu \mathrm{m}$. Paraphyses intermingled among conidiogenous cells, hyaline to pale brown, smooth to verruculose, 0 -2-septate, subcylindrical with obtuse ends, 30-50 × 3-4 $\mu \mathrm{m}$. Conidia solitary, hyaline, smooth, guttulate, subcylindrical to fusoid-ellipsoid, straight to curved, apex apiculate, tapering at base to truncate hilum, 2-4 $\mu \mathrm{m}$ diam, (36-)40-46(-53) $\times(7-) 8-9(-10)$ $\mu \mathrm{m}$; apex with flared mucoid appendage, up to $25 \mu \mathrm{m}$ long, $20 \mu \mathrm{m}$ diam (based on CPC 23897).

Culture characteristics:- Colonies dirty white on all media, with moderate aerial mycelium and feathery margins, covering dish in 1 mo.

Specimens examined:- FINLAND. Tuusula, Ruotsinkylä, on needles of Picea abies, 10 Sep. 1995, A.-M. Hallaksela, Tp D1 = CPC 23888; Tp T3 = 23890, Tp Q1 = 23892; 1994, H. Solheim, 89-2089-18 = CPC 23895; 1994, H. Solheim, (holotype CBS H-21852, culture ex-type 89-2090-16 = CPC 23897 = CBS 138576); Apr. 2008, M.M. Müller, He 392 = CPC 23900, He 394 = CPC 23901, He $397=23902$.

NORWAY. Mellesmo, Pasvik, on needles of P. abies, 1994, H. Solheim, 87-1491-1 = CPC 23879, 87-1491-2 = CPC 23880; Langtjern, 91-727-28 = CPC 23881; Nedstrand, 92-625-69 = CPC 23882. Switzerland, Lägern, on needles of P. abies, 30 Sep. 1986, $T$. Sieber, 90.140 = CPC 23883; Fiesch, 90.148 = CPC 23884; Lägern, 90.154 = CPC 238851; Davos, 90.155 = CPC 23886; 90.157 = CPC 23887.

Darkera pseudotsugae (H.S. Whitney, J. Reid \& Piroz.) Crous, comb. nov. MycoBank MB811247

Basionym: Tiarosporella pseudotsugae H.S. Whitney, J. Reid \& Piroz., Canadian Journal of Botany 53: 3057 (1975)

Note:- This taxon is known to occur on Pseudotsuga spp., with conidia being (33)40-65 × (4-)6-7 $\mu \mathrm{m}$ (Karadžić 1998). Based on its ecology (on conifer needles), as well as morphology (large unilocular conidiomata and long, wide conidia), it clearly is better accommodated in Darkera rather than Tiarosporella, and hence a new combination is herewith proposed for this taxon.

Higher order classification:- Dothideomycetes, Botryosphaeriales, Botryosphaeriaceae

Eutiarosporella Crous, gen. nov. MycoBank MB811248

Etymology:- Named after its morphological similarity to the genus Tiarosporella.

Distinguished from Tiarosporella by having conidiomata with long necks, and having holoblastic conidiogenesis. Similar to Marasasiomyces, except conidiomata frequently in clusters.

Conidiomata pycnidial, uni- to multilocular, dark brown to black, globose, rostrate with elongated necks, with or without setae, aggregated in clusters. Conidiophores reduced to conidiogenous cells. Conidiogenous cells lining the inner cavity, holoblastic, determinate, cylindrical, hyaline, smooth. Conidia solitary, hyaline, 
smooth, thin-walled, straight, ovoid to fusoid, apex obtuse, base truncate, with a conelike mucoid apical appendage.

Type species:- Eutiarosporella tritici (B. Sutton \& Marasas) Crous

Eutiarosporella africana (Jami, Gryzenh., Slippers \& M.J. Wingf.) Crous, comb. nov. MycoBank MB811249

Basionym: Tiarosporella africana Jami, Gryzenh., Slippers \& M.J. Wingf., Fungal Biology 118: 174 (2014)

Specimen examined:- SOUTH AFRICA. Gauteng Province, Pretoria, from healthy wood section of Celtis africana, Nov. 2011, F. Jami \& M. Gryzenhout (holotype PREM 60866, culture ex-type CMW 38423 = CBS 133854).

Eutiarosporella tritici (B. Sutton \& Marasas) Crous, comb. nov. MycoBank MB811250

Basionym: Tiarosporella tritici B. Sutton \& Marasas, Transactions of the British Mycological Society 67: 74 (1976)

Specimen examined:- SOUTH AFRICA. Free State Province: Heilbron, on Triticum aestivum, 18 Jan. 1973, W.F.O. Marasas (holotype PREM 44966, isotype IMI 186786, culture ex-type CBS 118719).

Eutiarosporella urbis-rosarum (Jami, Gryzenh., Slippers \& M.J. Wingf.) Crous, comb. nov. MycoBank MB811251

Basionym: Tiarosporella urbis-rosarum Jami, Gryzenh., Slippers \& M.J. Wingf., Cryptogamie, Mycologie 33: 256 (2012)

Specimen examined:- SOUTH AFRICA. Free State Province, Bloemfontein, healthy wood of Vachellia karroo, June 2008, M. Gryzenhout (holotype PREM 60698, culture ex-type CBS 130405).

Marasasiomyces Crous, gen. nov. MycoBank MB811252

Etymology:- Named after Walter Friedrich Otto Marasas, who collected this fungus in the Karoo, South Africa.

Distinguished from Tiarosporella by having conidiomata with long necks, covered in brown setae, and having holoblastic conidiogenesis. Similar to Eutiarosporella, but conidiomata not in clusters.

Conidiomata pycnidial, dark brown to black, rostrate with elongated necks, covered in brown, simple, septate, smooth to verruculose setae. Conidiophores reduced to conidiogenous cells. Conidiogenous cells lining the inner cavity, holoblastic, determinate, cylindrical, hyaline, smooth. Conidia solitary, hyaline, smooth, thin- 
walled, straight, fusiform, apex obtuse, base truncate, with a cone-like mucoid apical appendage.

Type species:- Marasasiomyces karoo (B. Sutton \& Marasas) Crous

Marasasiomyces karoo (B. Sutton \& Marasas) Crous, comb. et stat. nov. MycoBank MB811253

Basionym: Tiarosporella graminis var. karoo B. Sutton \& Marasas, Transactions of the British Mycological Society 67: 73 (1976)

Conidiomata pycnidial, dark brown to black, rostrate with elongated necks, covered in brown, simple, septate, smooth to verruculose setae. Conidiophores reduced to conidiogenous cells. Conidiogenous cells lining the inner cavity, holoblastic, determinate, cylindrical, hyaline, smooth, 12-18× 1.5-2.5 $\mu \mathrm{m}$. Conidia solitary, hyaline, smooth, thin-walled, straight, fusiform, apex obtuse, base truncate, 21-28 $\times$ 5-8 $\mu \mathrm{m}$, with a cone-like mucoid apical appendage.

Specimen examined:- SOUTH AFRICA. Cape Province: Colesberg, on dead stems of Eriocephalus sp., Feb. 1971, W.F.O. Marasas (holotype PREM 44967, isotype IMI 186782, culture ex-type CBS 118718).

Notes:- The peculiar conidiomata with elongated necks, covered in brown setae, was commented on when this fungus was originally described (Sutton \& Marasas 1976), and also illustrated subsequently (Crous et al. 2006, fig. 7). Furthermore, in a study elucidating the conidiogenesis of this fungus, Roux et al. (1990) did not find any evidence of percurrent proliferation, while this feature is again prominent in Tiarosporella s.str.

Mucoharknessia Crous, R.M. Sánchez \& Bianchin., gen. nov. MycoBank MB811254

Etymology:- Muco, derived from the mucoid appendage, and Harknessia (resembling the genus).

Mucoharknessia resembles Harknessia (Harknessiaceae, Diaporthales), but is distinguished from that genus by having pycnidia that lack furfuraceous tissue surrounding its ostiole, and conidia that have a mucoid apical appendage.

Foliicolous. Conidiomata immersed, separate or aggregated, pycnidial, unilocular, globose to subglobose, blackish on leaves; ostiole subepidermal, circular to subcircular, opening onto the abaxial side of leaves by means of a longitudinal split in epidermis. Peridium arranged in two layers, the external stromatic, with brown cells of textura angularis; the internal conformed by flattened, hyaline cells, $10-15 \mu \mathrm{m}$ thick. Conidiophores reduced to conidiogenous cells, lining the conidiomatal cavity. Conidiogenous cells lageniform to subcylindrical, smooth, covered in mucus, hyaline; proliferating several times percurrently at apex, with flared collarette visible. Conidia oval to ellipsoidal, appendaged, thick-walled, smooth to finely verruculose, lacking striations, brown; apical appendage extracellular (Type B, sensu Nag Raj 1993), mucilaginous, irregular, smooth, hyaline; basal appendage tubular, thin walled, smooth, hyaline, often collapsing. Microconidia not seen.

Type species:- Mucoharknessia cortaderiae Crous, R.M. Sánchez \& Bianchin. 

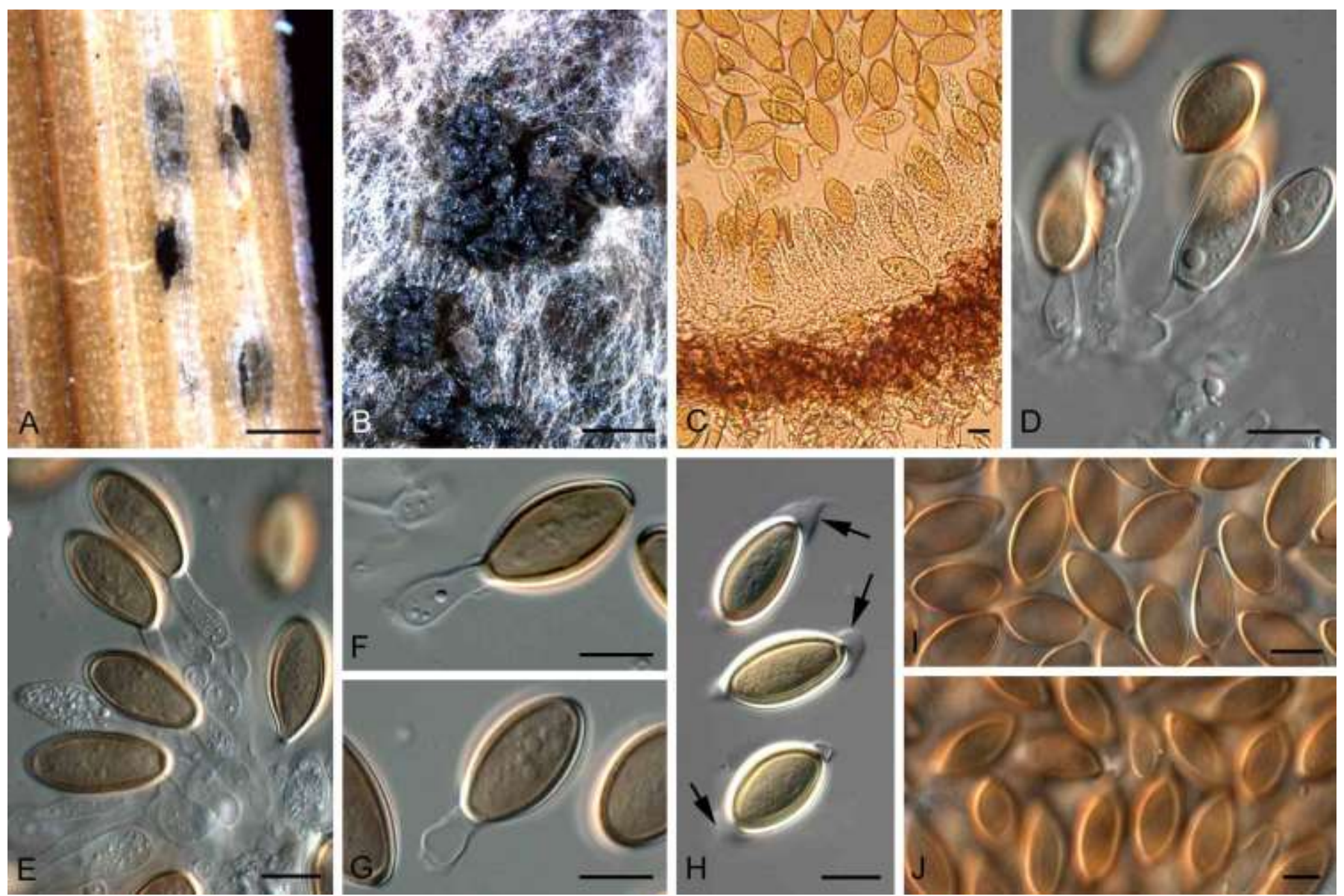

FIGURE 6. Mucoharknessia cortaderiae (CPC 19974). A. Conidiomata on leaf blade of Cortaderia selloana. B. Aggregated conidiomata forming on PDA. C. Vertical section through a pycnidium, showing wall anatomy. D-G. Conidiogenous cells giving rise to conidia (note collarettes, F, G). H. Appendaged conidia with arrows indicating apical mucoid caps. I, J. Brown, finely verruculose, ellipsoid conidia. Scale bars: A, B $=300 \mu \mathrm{m}$, all others $=10 \mu \mathrm{m}$. 
Mucoharknessia cortaderiae Crous, R.M. Sánchez \& Bianchin., sp. nov. MycoBank MB811255; Fig. 6

Etymology:- After the genus Cortaderia on which the fungus was first found.

Conidiomata immersed, separate or aggregated, pycnidial, unilocular, globose to subglobose, blackish on leaves, 110-315 $\mu \mathrm{m}$ high, 250-350 $\mu \mathrm{m}$ diam. Ostiole subepidermal, circular to subcircular, opening onto the abaxial side of leaves by means of a longitudinal split in epidermis; lacking furfuraceous tissue that surrounds ostiolar openings in Harknessia s.str. Peridium arranged in two layers, the external stromatic, with brown cells of textura angularis, 35-45 $\mu$ m thick; the internal conformed by flattened, hyaline cells, $10-15 \mu \mathrm{m}$ thick. Conidiophores reduced to conidiogenous cells, lining the conidiomatal cavity. Conidiogenous cells lageniform to subcylindrical, smooth, covered in mucus, hyaline, 7-18 $\mu \mathrm{m}$ long, 3-6 $\mu \mathrm{m}$ diam at the base, $2-4 \mu \mathrm{m}$ diam at the apex; proliferating several times percurrently at apex, with flared collarette visible. Conidia oval to ellipsoidal, appendaged, thick-walled, smooth to finely verruculose, lacking striations, brown, $(18-) 21-27(-39) \times(9-) 11-$ 12(-17) $\mu \mathrm{m}$; apical appendage extracellular (Type B, sensu Nag Raj 1993), mucilaginous, irregular, smooth, hyaline, 3-5 $\mu \mathrm{m}$ long, best seen with India ink; basal appendage tubular, thin walled, smooth, hyaline, 1-5 $\mu \mathrm{m}$ long, 3-5 $\mu \mathrm{m}$ diam, often collapsing. Microconidia not seen.

Cultural characteristics:- Colonies covering the dish in $2 \mathrm{wk}$, with sparse aerial mycelium, and even feathery margins; surface on MEA and PDA olivaceous grey, reverse iron grey.

Specimen examined:- ARGENTINA. Buenos Aires Province, Punta Alta, $38^{\circ} 47^{\prime} 27,6$ 'S $62^{\circ} 6^{\prime} 48,6$ 'W, on leaves of Cortaderia selloana (Schult. \& Schult. f.) Asch. \& Graebn. (Poaceae), 29 Mar. 2011, F.E. Anderson (holotype BBB, (MVB 1502), isotype CBS H-21853, culture ex-isotype CBS $131032=$ CPC 19974, CPC 22208, 22209).

Additional specimens examined:- all on leaves of Cortaderia selloana; ARGENTINA. Buenos Aires Province: La Paz, S35²1'32.5” W59¹9'57.2”, 30 May 2011, F.E. Anderson, C10; Miramar, S38¹3'12”'W57²2'51”, 18 Jul. 2011, L. Gallego, C14-1; Monte Hermoso, S38 59'9.5” W61 7'42.9, 24 Apr. 2011, F.E. Anderson, C7; Tandil, S37 $18^{\prime} 17.5^{\prime \prime}$ W59 $9^{\circ}$ '4.9”, 23 Apr. 2011, L. Gallego, C8-1, Tandil, S37'18'17.5"'W598'4.9”, 18 Jul. 2011, L. Gallego, C8-3.

Notes:- Conidiomata interveinal, associated with elongated, pale brown to yellowish or orange-brown necrotic leaf blade sections, most likely as a secondary invader, which proved to be rather uncommonly encountered. With its unilocular conidiomata, and pigmented, appendaged conidia, it is somewhat reminiscent of Harknessia (Crous et al. 2012) and Macrophomina (Sarr et al. 2014). Phylogenetically however, it proved to be allied to genera in the Tiarosporella complex in the Botryosphaeriaceae (Fig. 1), which was quite unexpected.

Sakireeta Subram. \& K. Ramakr., Journal of the Indian Botanical Society 36: 83 (1957)

Foliicolous. Conidiomata pycnidial, aggregated, immersed, depressed, globose, mostly irregularly multilocular in a stroma, dark brown, ostiolate; wall of 3-6 layers 


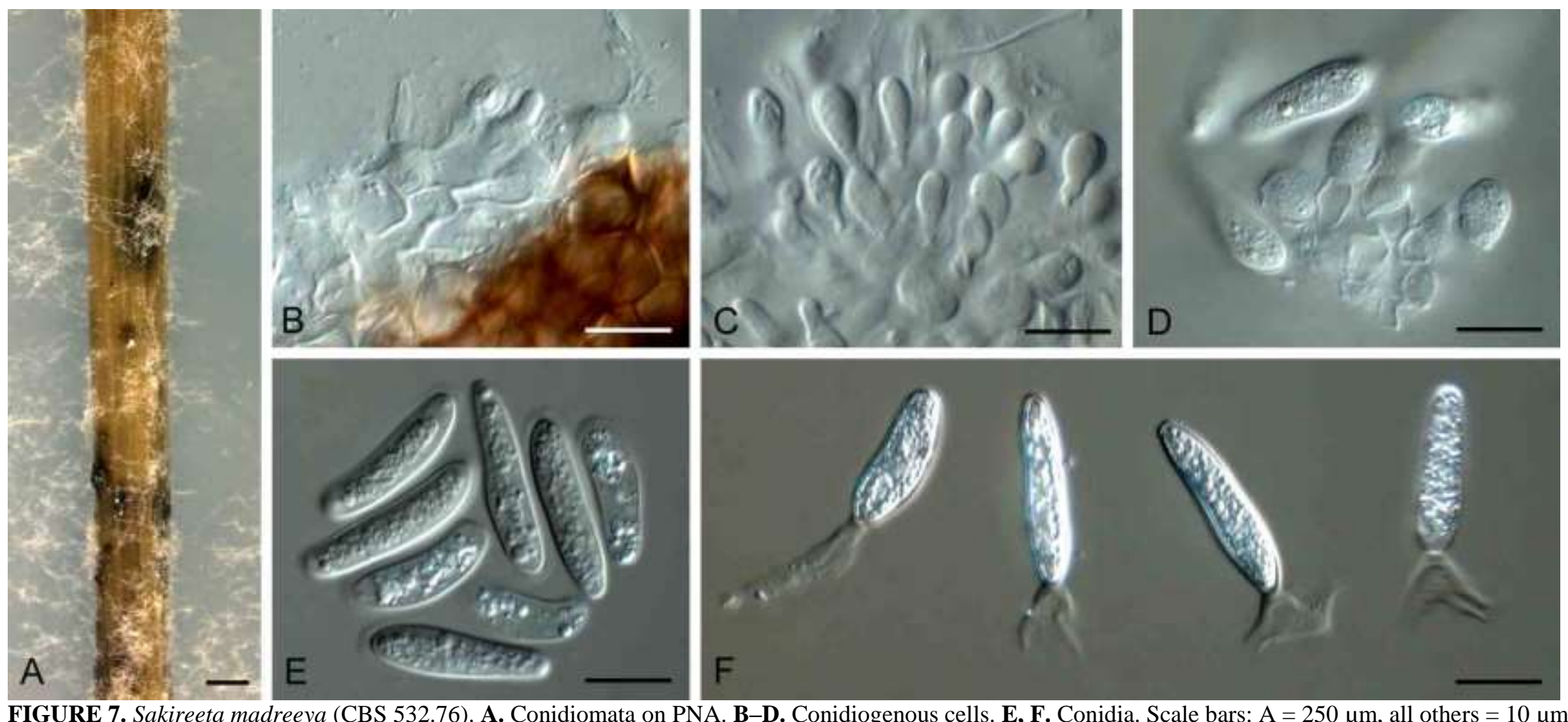


of brown textura angularis. Conidiophores reduced to conidiogenous cells. Conidiogenous cells hyaline, smooth, lining the inner cavity, subcylindrical to ampulliform; conidiogenesis holoblastic, lacking phialides with percurrent proliferation or periclinal thickening. Conidia subcylindrical to clavate or narrowly ellipsoid, apex obtuse, base truncate, aseptate, smooth, hyaline, granular, with apical cone-shaped appendage, which splits into up to four tentaculiform undulate appendages.

Type species:- Sakireeta madreeya Subram. \& K. Ramakr.

Sakireeta madreeya Subram. \& K. Ramakr., Journal of the Indian Botanical Society 36: 84 (1957); Fig. 7

Synonym: Tiarosporella madreeya (Subram. \& K. Ramakr.) Nag Raj, Canadian Journal of Botany 51: 2470 (1974) [1973]

Foliicolous. Conidiomata pycnidial, aggregated, immersed, depressed, globose, mostly irregularly multilocular in a stroma, dark brown, ostiolate; wall of 3-6 layers of brown textura angularis. Conidiophores reduced to conidiogenous cells.

Conidiogenous cells hyaline, smooth, lining the inner cavity, subcylindrical to ampulliform, 4-7 × 3-5 $\mu \mathrm{m}$; conidiogenesis holoblastic, lacking phialides with percurrent proliferation or periclinal thickening. Conidia $(15-) 18-25(-30) \times(4-) 5-$ $6(-7) \mu \mathrm{m}$, subcylindrical to clavate or narrowly ellipsoid, apex obtuse, base truncate, aseptate, smooth, hyaline, granular, with an apical cone-shaped appendage which splits into up to four tentaculiform undulate appendages.

Culture characteristics:- Colonies spreading, flat, with moderate, cottony aerial mycelium, and feathery margins. On MEA surface dirty white, reverse olivaceousblack. On OA surface olivaceous-grey.

Specimens examined:- INDIA. Madras, Choolai, on dead culm of Aristida setacea, 27 Sept. 1951, K. Ramakrishnan (holotype MUBL 631); Kurukshetra Univ., undetermined grass host, July 1976, R.S. Mehrotra, CBS H-21854, culture CBS 532.76 .

Notes:- The culture originally deposited as Tiarosporella madreeya from India (CBS 532.76) closely corresponds with the morphology of the type specimen, and therefore we regard it as authentic. However, as the host was never stipulated, and the laboratory records of Prof. R.S. Mehrotra (communicated via Dr K.C. Rajeshkumar) indicate that it was collected as a saprobe from grasses buried in soil for decomposition. As it is impossible to accurately identify the host, we thus refrain from designating it as epitype for the genus.

Of interest is that the type of Tiarosporella, T. paludosa, has solitary unilocular conidiomata, whereas those of Sakireeta madreeya are aggregated in a stroma, and plurilocular. Furthermore, T. paludosa has percurrently proliferating conidiogenous cells, whereas those of Sakireeta madreeya are holoblastic. Once more species of these two genera have been collected and subjected to DNA analysis to confirm their generic placement, it will be possible to confirm if these characters are also valuable at the generic level in distinguishing Tiarosporella from Sakireeta.

Tiarosporella Höhn., Berichte der Deutschen Botanischen Gesellschaft 37: 159 (1919)

Foliicolous, rarely caulicolous. Conidiomata pycnidial, separate, immersed, globose 

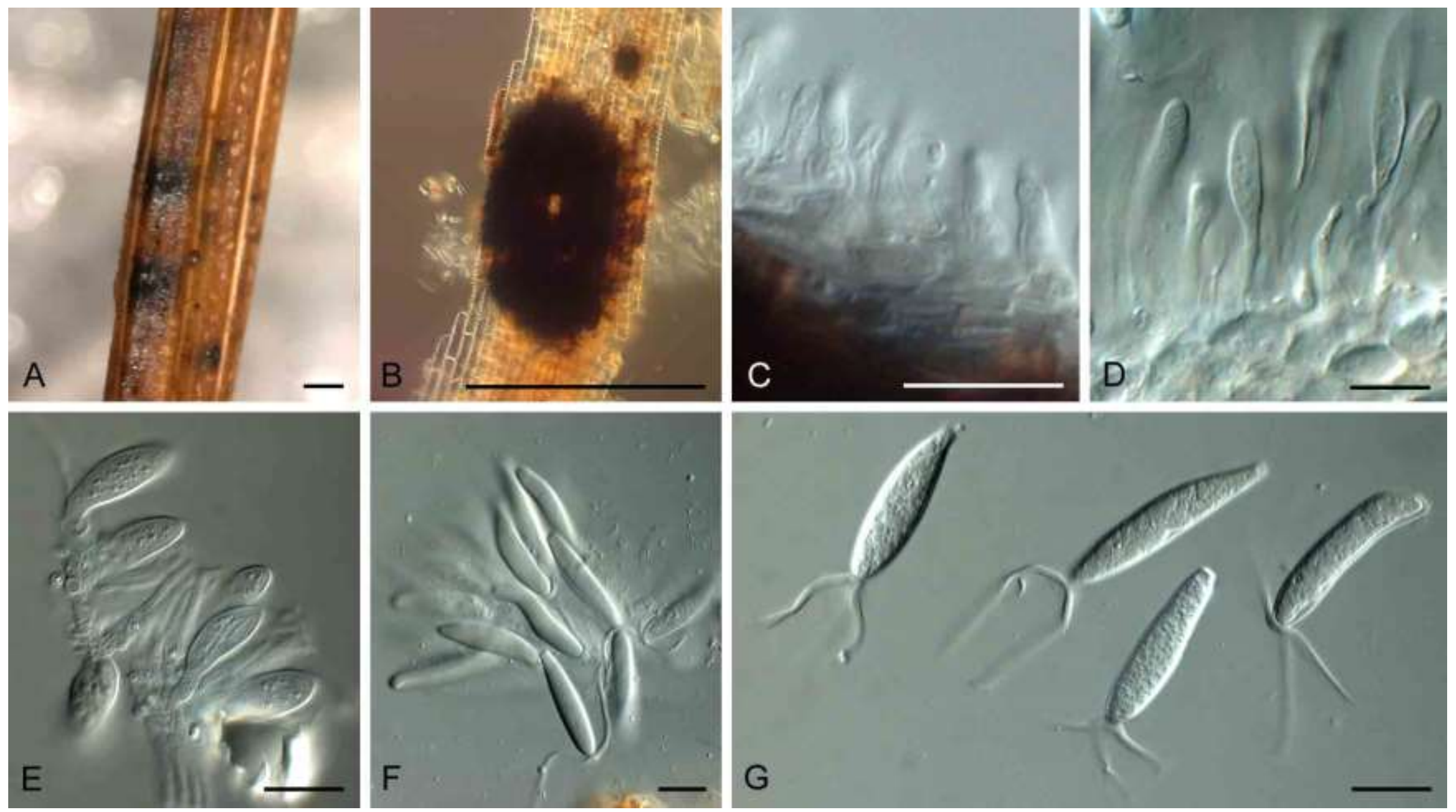

FIGURE 8. Tiarosporella paludosa (CPC 22701). A, B. Conidiomata on PNA. C-E. Conidiogenous cells. F, G. Conidia. Scale bars: A, B $=250 \mu \mathrm{m}$, all others $=10 \mu \mathrm{m}$. 
to depressed, unilocular, dark brown, with central substomatal ostiole; wall of brown textura angularis. Conidiophores reduced to conidiogenous cells lining the inner cavity. Conidiogenous cells hyaline, smooth, subcylindrical to ampulliform, encased in mucus, proliferating percurrently near the apex. Conidia hyaline, smooth, solitary, subcylindrical to subclavate, apex subobtuse, base truncate, rarely with marginal frill, aseptate, bearing 2-4 tentaculiform, undulate apical mucoid appendages. The conidium is initially covered in a mucoid sheath, which splits longitudinally, resulting in apical tentaculiform appendages.

Type species:- Tiarosporella paludosa (Sacc. \& Fiori ex P. Syd.) Höhn.

Tiarosporella paludosa (Sacc. \& Fiori) Höhn., Berichte der Deutschen Botanischen Gesellschaft 37: 159 (1919); Fig. 8

Basionym: Neottiospora paludosa Sacc. \& Fiori, Hedwigia Beiblätter 38: 137 (1899) Additional synonyms listed by Nag Raj (1993).

Foliicolous. Conidiomata pycnidial, separate, immersed, globose to depressed, 200 $350 \mu \mathrm{m}$ diam, unilocular, dark brown, with central substomatal ostiole; wall of brown textura angularis, 20-40 $\mu \mathrm{m}$ thick. Conidiophores reduced to conidiogenous cells lining the inner cavity. Conidiogenous cells hyaline, smooth, subcylindrical to ampulliform, encased in mucus, $6-15 \times 1.5-3.5 \mu \mathrm{m}$, proliferating percurrently near the apex. Conidia hyaline, smooth, solitary, subcylindrical to subclavate, apex subobtuse, base truncate, $2-3 \mu \mathrm{m}$ diam, rarely with marginal frill, $1 \mu \mathrm{m}$ long; conidia aseptate, widest in upper third of conidium, (22-)30-38(-45) $\times(4-) 5-6(-7) \mu \mathrm{m}$, bearing 2-4 tentaculiform, undulate apical mucoid appendages. The conidium is initially covered in a mucoid sheath, which splits longitudinally, resulting in apical tentaculiform appendages.

Culture characteristics:- Colonies fast growing, covering the dish in 2 wk; grey olivaceous on surface and olivaceous black in reverse, with fluffy aerial mycelium and even, feathery margins.

Specimens examined:- GERMANY. Berlin, Zahlendorf, on leaves of Eriophorum polystachium, Oct. 1895, P. Sydow (holotype in FH, isotype DAOM 130546). NETHERLANDS. Winterswijk in the Korenburgerveen, Latitude 51.990133, Longitude 6.664013, on Trichophorum cespitosum subsp. germanicum, 28 Apr. 2013, W. Quaedvlieg (epitype designated here CBS H-21855 MBT200481, culture exepitype CPC 22701, 22702 = CBS 138577). SWEDEN. Åland, Eckerö par., on Eleocharis palustris, 14 Sep. 1990, K. \& L. Holm, UPSC 3256 = CBS 114650. Notes:- Tiarosporella paludosa occurs rather commonly in Germany on Carex spp., Eriophorum polystachium and Trichophorum cespitosum (= Scirpus caespitosus) (Sutton 1980, Nag Raj 1993), and is obviously widely distributed in Europe. It is also known to occur in Canada and the USA (Nag Raj 1993). The present collection closely matches the morphology of the holotype, and is also from Germany, where this taxon occurs commonly on Carex, Eriophorum and Trichophorum (Sutton 1980, Nag Raj 1993). Phylogenetically it is identical to another culture of T. paludosa from Eleocharis palustris (CBS 114650; sterile) collected in Sweden (Table 1), justifying CBS H-21855 as an excellent epitype specimen for the taxon, which also fixes the genetic application of the name. 
TABLE 1. Collection details and GenBank accession numbers of isolates included in this study.

\begin{tabular}{|c|c|c|c|c|c|c|c|c|c|}
\hline \multirow{2}{*}{ Species } & \multirow{2}{*}{ Culture collection no ${ }^{1}$} & \multirow{2}{*}{ Substrate } & \multirow{2}{*}{ Location } & \multirow{2}{*}{ Collector } & \multicolumn{5}{|c|}{ GenBank Accession no ${ }^{2}$} \\
\hline & & & & & ITS & LSU & TEF & TUB & SSU \\
\hline \multirow{4}{*}{$\begin{array}{l}\text { Barriopsis fusca } \\
\text { Botryobambusa } \\
\text { fusicoccum }\end{array}$} & CBS 174.26 ex-type & Twigs of Citrus sp. & Cuba & N.E. Stevens & EU673330 & DQ377857 & - & - & - \\
\hline & CBS 134113; CPC & Dead culms of & Thailand: & R. Phookamsak & JX646792 & JX646809 & - & - & - \\
\hline & $\begin{array}{l}\text { 21558; MFLUCC } 11- \\
0143 \text { ex-type }\end{array}$ & Bambusa species & Lampang Province & & & & & & \\
\hline & MFLUCC 11-0657 & $\begin{array}{l}\text { Dead culms of } \\
\text { Bambusa species }\end{array}$ & $\begin{array}{l}\text { Thailand: } \\
\text { Lampang Province }\end{array}$ & R. Phookamsak & JX646793 & JX646810 & - & - & - \\
\hline $\begin{array}{l}\text { Botryosphaeria } \\
\text { agaves }\end{array}$ & $\begin{array}{l}\text { CBS 133992; CPC } \\
\text { 21559; MFLUCC 11- } \\
\text { 0125 ex-neotype }\end{array}$ & Leaves of Agave sp. & $\begin{array}{l}\text { Thailand: Chiang } \\
\text { Rai Province }\end{array}$ & R. Phookamsak & JX646791 & JX646808 & - & - & - \\
\hline $\begin{array}{l}\text { Botryosphaeria } \\
\text { corticis }\end{array}$ & $\begin{array}{l}\text { CBS 119047; CAP } \\
197 \text { ex-epitype }\end{array}$ & $\begin{array}{l}\text { Stems of Vaccinium } \\
\text { corymbosum }\end{array}$ & USA: New Jersey & P.V. Oudemans & DQ299245 & EU673244 & - & - & - \\
\hline $\begin{array}{l}\text { Botryosphaeria } \\
\text { dothidea }\end{array}$ & $\begin{array}{l}\text { CBS 110302; CAP } \\
007\end{array}$ & Vitis vinifera & Portugal & A.J.L. Phillips & AY259092 & DQ377851 & - & - & - \\
\hline $\begin{array}{l}\text { Cophinforma } \\
\text { eucalypti }\end{array}$ & MFLUCC 11-0655 & $\begin{array}{l}\text { Dead branch of } \\
\text { Eucalyptus sp. }\end{array}$ & $\begin{array}{l}\text { Thailand: Chiang } \\
\text { Rai Province }\end{array}$ & M. Doilom & JX646801 & JX646818 & - & - & - \\
\hline Cophinforma mamane & $\begin{array}{l}\text { CBS 117444; CMW } \\
13416\end{array}$ & Eucalyptus urophylla & Venezuela & S. Mohali & KF531822 & DQ377855 & - & - & - \\
\hline \multirow[t]{2}{*}{ Darkera parca } & CPC 23903 & $\begin{array}{l}\text { Green healthy needle of } \\
\text { Picea abies var. } \\
\text { obovata }\end{array}$ & Siberia & M.M. Müller & KM108354 & KM108381 & KM108407 & KM108452 & KM108430 \\
\hline & СРC 23904 & $\begin{array}{l}\text { Green healthy needle of } \\
\text { Picea abies var. } \\
\text { obovata }\end{array}$ & Siberia & M.M. Müller & KM108355 & KM108382 & KM108408 & KM108453 & KM108431 \\
\hline \multirow[t]{10}{*}{ Darkera picea } & СРC 23879 & $\begin{array}{l}\text { Needle of Picea abies, } \\
\text { pycnidium }\end{array}$ & Norway & H. Solheim & KM108356 & KM108383 & KM108409 & KM108454 & KM108432 \\
\hline & CPC 23880 & $\begin{array}{l}\text { Needle of Picea abies, } \\
\text { pycnidium }\end{array}$ & Norway & H. Solheim & KM108357 & KM108384 & KM108410 & KM108455 & KM108433 \\
\hline & СРC 23881 & Needle of Picea abies & Norway & H. Solheim & KM108358 & KM108385 & KM108411 & KM108456 & KM108434 \\
\hline & CPC 23882 & Needle of Picea abies & Norway & H. Solheim & KM108359 & KM108386 & KM108412 & KM108457 & KM108435 \\
\hline & СРC 23883 & Needle of Picea abies & Switzerland & T. Sieber & KM108360 & KM108387 & KM108413 & KM108458 & KM108436 \\
\hline & CPC 23884 & Needle of Picea abies & Switzerland & T. Sieber & KM108361 & KM108388 & KM108414 & - & KM108437 \\
\hline & CPC 23885 & Needle of Picea abies & Switzerland & T. Sieber & KM108362 & KM108389 & KM108415 & KM108459 & KM108438 \\
\hline & СРC 23886 & Needle of Picea abies & Switzerland & T. Sieber & KM108363 & KM108390 & KM108416 & KM108460 & KM108439 \\
\hline & CPC 23887 & - & Switzerland & T. Sieber & KM108364 & KM108391 & KM108417 & KM108461 & KM108440 \\
\hline & СРC 23888 & Needle of Picea abies, & Finland & A.-M. Hallaksela & KM108365 & KM108392 & KM108418 & KM108462 & KM108441 \\
\hline
\end{tabular}




\begin{tabular}{|c|c|c|c|c|c|c|c|c|c|}
\hline & СРC 23890 & $\begin{array}{l}\text { pycnidium } \\
\text { Needle of Picea abies, } \\
\text { pycnidium }\end{array}$ & Finland & A.-M. Hallaksela & KM108366 & KM108393 & KM108419 & KM108463 & KM108442 \\
\hline & СРC 23892 & $\begin{array}{l}\text { Needle of Picea abies, } \\
\text { pycnidium }\end{array}$ & Finland & A.-M. Hallaksela & KM108367 & KM108394 & KM108420 & KM108464 & KM108443 \\
\hline & CPC 23895 & Picea abies & Finland & H. Solheim & KM108368 & KM108395 & KM108421 & KM108465 & KM108444 \\
\hline & СРC 23896 & Picea abies & Finland & H. Solheim & KM108369 & KM108396 & KM108422 & - & KM108445 \\
\hline & СРC 23897 & Picea abies & Finland & H. Solheim & KM108370 & KM108397 & KM108423 & KM108466 & KM108446 \\
\hline & СРC 23900 & $\begin{array}{l}\text { Green healthy needle of } \\
\text { Picea abies }\end{array}$ & Finland & M.M. Müller & KM108371 & KM108398 & KM108424 & KM108467 & KM108447 \\
\hline & СРC 23901 & $\begin{array}{l}\text { Green healthy needle of } \\
\text { Picea abies }\end{array}$ & Finland & M.M. Müller & KM108372 & KM108399 & KM108425 & KM108468 & KM108448 \\
\hline & СРC 23902 & $\begin{array}{l}\text { Green healthy needle of } \\
\text { Picea abies }\end{array}$ & Finland & M.M. Müller & KM108373 & KM108400 & KM108426 & KM108469 & KM108449 \\
\hline Diplodia mutila & CBS 230.30 & Phoenix dactylifera & USA: California & - & DQ458886 & EU673265 & - & - & - \\
\hline Diplodia rosulata & CBS 116470 ex-type & $\begin{array}{l}\text { Seeds of Prunus } \\
\text { africana }\end{array}$ & Ethiopia & A. Gure & EU430265 & DQ377896 & - & - & - \\
\hline Diplodia sapinea & $\begin{array}{l}\text { CBS } 393.84 \text { ex- } \\
\text { epitype }\end{array}$ & Cones of Pinus nigra & $\begin{array}{l}\text { Netherlands: } \\
\text { Gelderland }\end{array}$ & H.A. van der Aa & DQ458895 & EU754157 & - & - & - \\
\hline Diplodia seriata & $\begin{array}{l}\text { CBS } 112555 \text { ex- } \\
\text { epitype }\end{array}$ & $\begin{array}{l}\text { Dead stems of Vitis } \\
\text { vinifera }\end{array}$ & Portugal & A.J.L. Phillips & AY259094 & KF766327 & - & - & - \\
\hline Diplodia tsugae & $\begin{array}{l}\text { CBS } 418.64 \text { ex- } \\
\text { isotype }\end{array}$ & $\begin{array}{l}\text { Branches of Tsuga } \\
\text { heterophylla }\end{array}$ & $\begin{array}{l}\text { Canada: British } \\
\text { Columbia }\end{array}$ & A. Funk & DQ458888 & DQ377867 & - & - & - \\
\hline \multirow[t]{3}{*}{$\begin{array}{l}\text { Eutiarosporella } \\
\text { africana }\end{array}$} & $\begin{array}{l}\text { CBS 133854; CMW } \\
38423 \text { ex-type }\end{array}$ & $\begin{array}{l}\text { Healthy wood section } \\
\text { of Celtis africana }\end{array}$ & $\begin{array}{l}\text { South Africa: } \\
\text { Gauteng Province }\end{array}$ & $\begin{array}{l}\text { F. Jami \& M. } \\
\text { Gryzenhout }\end{array}$ & KC769956 & KC769990 & KC769852 & KC769903 & - \\
\hline & $\begin{array}{l}\text { CBS 135850; CMW } \\
38424\end{array}$ & $\begin{array}{l}\text { Healthy branches of } \\
\text { Celtis africana }\end{array}$ & $\begin{array}{l}\text { South Africa: } \\
\text { Gauteng Province }\end{array}$ & $\begin{array}{l}\text { F. Jami \& M. } \\
\text { Gryzenhout }\end{array}$ & KC769957 & КC769991 & KC769853 & KC769904 & - \\
\hline & $\begin{array}{l}\text { CBS 135851; CMW } \\
38425\end{array}$ & $\begin{array}{l}\text { Healthy branches of } \\
\text { Celtis africana }\end{array}$ & $\begin{array}{l}\text { South Africa: } \\
\text { Gauteng Province }\end{array}$ & $\begin{array}{l}\text { F. Jami \& M. } \\
\text { Gryzenhout }\end{array}$ & KC769958 & KC769992 & KC769854 & KC769905 & - \\
\hline Eutiarosporella tritici & $\begin{array}{l}\text { CBS } 118719 ; \text { IMI } \\
186786 \text { ex-type }\end{array}$ & Triticum aestivum & $\begin{array}{l}\text { South Africa: Free } \\
\text { State Province }\end{array}$ & W.F.O. Marasas & KF531830 & DQ377941 & KF531809 & KF531810 & KF531829 \\
\hline \multirow[t]{3}{*}{$\begin{array}{l}\text { Eutiarosporella urbis- } \\
\text { rosarum }\end{array}$} & $\begin{array}{l}\text { CBS } 130405 ; \text { CMW } \\
36477 \text { ex-type }\end{array}$ & $\begin{array}{l}\text { Healthy branches of } \\
\text { Acacia karroo }\end{array}$ & $\begin{array}{l}\text { South Africa: Free } \\
\text { State Province }\end{array}$ & M. Gryzenhout & JQ239407 & JQ239420 & JQ239394 & JQ239381 & - \\
\hline & $\begin{array}{l}\text { CBS 130406; CMW } \\
36478 \text { ex-paratype }\end{array}$ & $\begin{array}{l}\text { Healthy branches of } \\
\text { Acacia karroo }\end{array}$ & $\begin{array}{l}\text { South Africa: Free } \\
\text { State Province }\end{array}$ & M. Gryzenhout & JQ239408 & JQ239421 & JQ239395 & JQ239382 & - \\
\hline & $\begin{array}{l}\text { CBS 130407; CMW } \\
36479\end{array}$ & $\begin{array}{l}\text { Healthy branches of } \\
\text { Acacia karroo }\end{array}$ & $\begin{array}{l}\text { South Africa: Free } \\
\text { State Province }\end{array}$ & M. Gryzenhout & JQ239409 & JQ239422 & JQ239396 & JQ239383 & - \\
\hline $\begin{array}{l}\text { Lasiodiplodia } \\
\text { crassispora }\end{array}$ & $\begin{array}{l}\text { CBS 118741; CMW } \\
\text { 14691; WAC } 12533 \\
\text { ex-type }\end{array}$ & Santalum album & $\begin{array}{l}\text { Australia: Western } \\
\text { Australia }\end{array}$ & T.I. Burgess & DQ103550 & DQ377901 & - & - & - \\
\hline
\end{tabular}




\begin{tabular}{|c|c|c|c|c|c|c|c|c|c|}
\hline $\begin{array}{l}\text { Lasiodiplodia } \\
\text { gonubiensis }\end{array}$ & $\begin{array}{l}\text { CBS 115812; CMW } \\
14077 \text { ex-type }\end{array}$ & Syzygium cordatum & $\begin{array}{l}\text { South Africa: } \\
\text { Eastern Cape } \\
\text { Province }\end{array}$ & D. Pavlic & DQ458892 & DQ377902 & - & - & - \\
\hline $\begin{array}{l}\text { Lasiodiplodia } \\
\text { lignicola }\end{array}$ & $\begin{array}{l}\text { MFLUCC 11-0435 } \\
\text { ex-type }\end{array}$ & Dead wood & $\begin{array}{l}\text { Thailand: Chiang } \\
\text { Rai Province }\end{array}$ & A.D Ariyawansa & JX646797 & JX646814 & - & - & - \\
\hline Lasiodiplodia parva & CBS 456.78 ex-type & Cassava field soil & Colombia & O. Rangel & KF766192 & KF766362 & - & - & - \\
\hline $\begin{array}{l}\text { Lasiodiplodia } \\
\text { pseudotheobromae }\end{array}$ & CBS 447.62 & $\begin{array}{l}\text { Fruit of Citrus } \\
\text { aurantium }\end{array}$ & Suriname & - & EF622081 & EU673255 & - & - & - \\
\hline $\begin{array}{l}\text { Lasiodiplodia } \\
\text { rubropurpurea }\end{array}$ & $\begin{array}{l}\text { CBS 118740; CMW } \\
\text { 14700; WAC } 12535 \\
\text { ex-type }\end{array}$ & $\begin{array}{l}\text { Canker on Eucalyptus } \\
\text { grandis }\end{array}$ & $\begin{array}{l}\text { Australia: } \\
\text { Queensland }\end{array}$ & T.I. Burgess & DQ103553 & DQ377903 & - & - & - \\
\hline $\begin{array}{l}\text { Lasiodiplodia } \\
\text { theobromae }\end{array}$ & MFLUCC 11-0508 & $\begin{array}{l}\text { Dead twig of } \\
\text { Eucalyptus sp. }\end{array}$ & $\begin{array}{l}\text { Thailand: Chiang } \\
\text { Rai Province }\end{array}$ & M. Doilom & JX646799 & JX646816 & - & - & - \\
\hline $\begin{array}{l}\text { Lasiodiplodia } \\
\text { venezuelensis }\end{array}$ & $\begin{array}{l}\text { CBS 118739; CMW } \\
\text { 13511; WAC } 12539 \\
\text { ex-type }\end{array}$ & $\begin{array}{l}\text { Wood of living Acacia } \\
\text { mangium }\end{array}$ & Venezuela & S. Mohali & DQ103547 & DQ377904 & - & - & - \\
\hline \multirow[t]{2}{*}{$\begin{array}{l}\text { Macrophomina } \\
\text { phaseolina }\end{array}$} & CBS 162.25 & Eucalyptus sp. & Uganda & - & KF531826 & DQ377905 & - & - & - \\
\hline & CBS 227.33 & Zea mays & Palestine & - & KF531825 & DQ377906 & - & - & - \\
\hline $\begin{array}{l}\text { Marasasiomyces } \\
\text { karoo }\end{array}$ & $\begin{array}{l}\text { CBS } 118718 ; \text { IMI } \\
186782 \text { ex-type }\end{array}$ & $\begin{array}{l}\text { Dead stems of } \\
\text { Eriocephalus sp. }\end{array}$ & $\begin{array}{l}\text { South Africa: } \\
\text { Cape Province }\end{array}$ & W.F.O. Marasas & KF531828 & DQ377939 & KF531807 & KF531808 & KF531827 \\
\hline $\begin{array}{l}\text { Mucoharknessia } \\
\text { cortaderiae }\end{array}$ & CPC 19974 ex-type & $\begin{array}{l}\text { Leaves of Cortaderia } \\
\text { selloana }\end{array}$ & $\begin{array}{l}\text { Argentina: Buenos } \\
\text { Aires Province }\end{array}$ & F.E. Anderson & KM108374 & KM108401 & - & - & - \\
\hline $\begin{array}{l}\text { Mucoharknessia } \\
\text { cortaderiae }\end{array}$ & СРC 22208 & $\begin{array}{l}\text { Leaves of Cortaderia } \\
\text { selloana }\end{array}$ & $\begin{array}{l}\text { Argentina: Buenos } \\
\text { Aires Province }\end{array}$ & F.E. Anderson & KM108375 & KM108402 & - & - & - \\
\hline $\begin{array}{l}\text { Neodeightonia } \\
\text { palmicola }\end{array}$ & MFLUCC 10-0823 & Caryota urens & Thailand & $\begin{array}{l}\text { J.K. Liu \& R. } \\
\text { Phookamsak }\end{array}$ & HQ199224 & HQ199225 & - & - & - \\
\hline $\begin{array}{l}\text { Neodeightonia } \\
\text { phoenicum }\end{array}$ & CBS 122528 ex-type & Phoenix sp. & Spain: Catalonia & F. Garcia & KF766198 & EU673261 & - & - & - \\
\hline $\begin{array}{l}\text { Neodeightonia } \\
\text { subglobosa }\end{array}$ & CBS 448.91 ex-type & $\begin{array}{l}\text { Dead culms of } \\
\text { Bambusa arundinacea }\end{array}$ & Sierra Leone & F.C. Deighton & KF766199 & DQ377866 & - & - & - \\
\hline \multirow[t]{2}{*}{$\begin{array}{l}\text { Neoscytalidium } \\
\text { dimidiatum }\end{array}$} & $\begin{array}{l}\text { CBS } 145.78 \text { ex- } \\
\text { isotype }\end{array}$ & Sole of human foot & United Kingdom & C.K. Campbell & KF531816 & DQ377922 & - & - & - \\
\hline & $\begin{array}{l}\text { CBS 251.49; IMI } \\
\text { 031449; UAMH } 6803\end{array}$ & Juglans regia & USA: California & - & KF531819 & DQ377923 & - & - & - \\
\hline \multirow[t]{2}{*}{$\begin{array}{l}\text { Phaeobotryon } \\
\text { mamane }\end{array}$} & СРC 12264 & Sophora chrysophylla & USA: Hawaii & W. Gams & EU673331 & DQ377898 & - & - & - \\
\hline & CPC 12440 & Sophora chrysophylla & USA: Hawaii & W. Gams & EU673332 & EU673248 & - & - & - \\
\hline Saccharata proteae & $\begin{array}{l}\text { CBS 115206; CPC } \\
4378\end{array}$ & Protea sp. & Australia & M.E. Palm & KF531812 & GU301869 & - & - & - \\
\hline
\end{tabular}




\begin{tabular}{|c|c|c|c|c|c|c|c|c|c|}
\hline Sakireeta madreeya & CBS 532.76 & $\begin{array}{l}\text { Undetermined grass } \\
\text { host }\end{array}$ & India: Madras & R.S. Mehrotra & KM108376 & DQ377940 & KM108427 & - & - \\
\hline Sphaeropsis citrigena & ICMP 16812 ex-type & $\begin{array}{l}\text { Recently dead bark- } \\
\text { covered twigs of Citrus } \\
\text { sinensis }\end{array}$ & $\begin{array}{l}\text { New Zealand: } \\
\text { Northland }\end{array}$ & $\begin{array}{l}\text { S.R. Pennycook, } \\
\text { P.R. Johnston \& } \\
\text { B.C. Paulus }\end{array}$ & EU673328 & EU673246 & - & - & - \\
\hline $\begin{array}{l}\text { Sphaeropsis } \\
\text { eucalypticola }\end{array}$ & $\begin{array}{l}\text { CBS 133993; } \\
\text { MFLUCC 11-0579 } \\
\text { ex-type }\end{array}$ & $\begin{array}{l}\text { Dead twig of } \\
\text { Eucalyptus sp. }\end{array}$ & $\begin{array}{l}\text { Thailand: Chiang } \\
\text { Rai Province }\end{array}$ & M. Doilom & JX646802 & JX646819 & - & - & - \\
\hline Sphaeropsis porosa & $\begin{array}{l}\text { CBS 110496; CPC } \\
5132 \text { ex-type }\end{array}$ & Vitis vinifera & $\begin{array}{l}\text { South Africa: } \\
\text { Western Cape } \\
\text { Province }\end{array}$ & J.M. van Niekerk & AY343379 & DQ377894 & - & - & - \\
\hline Sphaeropsis visci & CBS 100163 & $\begin{array}{l}\text { Dead fallen twigs of } \\
\text { Viscum album, under } \\
\text { Populus sp. }\end{array}$ & Luxembourg & H.A. van der Aa & EU673324 & DQ377870 & - & - & - \\
\hline \multirow[t]{3}{*}{$\begin{array}{l}\text { Tiarosporella } \\
\text { paludosa }\end{array}$} & $\begin{array}{l}\text { CBS 114650; UPSC } \\
3256\end{array}$ & Eleocharis palustris & Sweden & K. \& L. Holm & KM108377 & KM108403 & KM108428 & KM108470 & - \\
\hline & $\begin{array}{l}\text { CPC } 22701 \text { ex- } \\
\text { epitype }\end{array}$ & $\begin{array}{l}\text { Trichophorum } \\
\text { cespitosum subsp. } \\
\text { germanicum }\end{array}$ & $\begin{array}{l}\text { Netherlands: } \\
\text { Winterswijk }\end{array}$ & W. Quaedvlieg & KM108378 & KM108404 & - & KM108471 & KM108450 \\
\hline & СРC 22702 & $\begin{array}{l}\text { Trichophorum } \\
\text { cespitosum subsp. } \\
\text { germanicum }\end{array}$ & $\begin{array}{l}\text { Netherlands: } \\
\text { Winterswijk }\end{array}$ & W. Quaedvlieg & KM108379 & KM108405 & - & KM108472 & KM108451 \\
\hline Tiarosporella sp. & $\begin{array}{l}\text { CBS 109699; LYN } \\
451\end{array}$ & $\begin{array}{l}\text { Leaf spot on } \\
\text { Xanthorrhoea sp. }\end{array}$ & Australia & C.F. Hill & KM108380 & KM108406 & KM108429 & - & - \\
\hline
\end{tabular}

${ }^{1}$ CAP: AJL Phillips, Universidade Nova de Lisboa, Portugal; CBS: CBS-KNAW Fungal Biodiversity Centre, Utrecht, The Netherlands; CMW: Tree Pathology Co-operative Program, Forestry Plants, Landcare Research, Aukland, New Zealand; IMI: International Mycological Institute, CBI-Bioscience, Egham, Bakeham Lane, UK; LYN: Private culture collection Frank Hill, New

Zealand; MFLUCC: Mae Fah Luang University Culture Collection, Chiang Mai, Thailand; UAMH: University of Alberta Mold Herbarium and Culture Collection, Edmonton, Canada; UPSC: Uppsala University Culture Collection of Fungi, Botanical Museum University of Uppsala, Uppsala, Sweden; WAC: Department of Agriculture, Western Australia Plant Pathogen Collection, South Perth, Western Australia.

${ }^{2}$ ITS: internal transcribed spacers and intervening 5.8S nrDNA; LSU: large subunit (28S) of the nrRNA gene operon; TEF: partial translation elongation factor 1-alpha gene; TUB: partial betatubulin gene; SSU: small subunit (18S) of the nrRNA gene operon. 


\section{Discussion}

Results from the present study revealed that the genus Tiarosporella s.lat. is actually poly- and paraphyletic. Tiarosporella-like taxa cluster in the Phacidiaceae, and Botryosphaeriaceae. Species of Tiarosporella s.str. belong to the Botryosphaeriaceae. Those species clustering in the Phacidiaceae (see Crous et al. 2014), are associated with needle diseases of conifers (Karadžić 1998, Müller \& Hantula 1998), and would be better allocated to the genus Darkera, for which a new species, D. picea, occurring on Picea spp. in Finland, Norway and Switzerland is introduced. This species is closely related to $D$. parca which occurs according to morphological characteristics both in Siberia and Canada and possibly also in Europe. Further collections are required, however, to resolve the status of D. parca in northern boreal forests, to determine if this is a morphologically variable taxon, or if several different species are involved, the species in the UK having somewhat larger conidia than the species occurring in Canada and Siberia.

Furthermore, the epitypification of Tiarosporella, based on T. paludosa, allowed us to separate this genus from its close allies in the Botryosphaeriaceae that actually form a subclade (Fig. 2), representing several genera with conidial appendages. This subclade includes genera such as Botryobambusa (see Liu et al. 2012 fig. 11, though appendage overlooked by the authors), and two new genera, namely Marasasiomyces, and Eutiarosporella. Eutiarosporella is morphologically similar to Marasasiomyces (long necked, hairy conidiomata, and holoblastic conidiogenesis), except that it forms conidiomata in clusters, which is not the case in Marasasiomyces. The latter two genera are distinguished from Tiarosporella by having conidiomata with elongated necks, and holoblastic conidiogenesis, while Tiarosporella has globose to depressed, unilocular conidiomata and conidiogenous cells with percurrent proliferation. Marasasiomyces and Eutiarosporella cluster sister to the genus Mucoharknessia, which appears harknessia-like in general morphology. The genus Harknessia (Harknessiaceae, Diaporthales; Crous et al. 2012) is similar to Apoharknessia (conidia with apical apiculus, short basal appendage, and percurrent proliferating conidiogenous cells; Lee et al. 2004) and Dwiroopa (conidia with prominent longitudinal conidial germ slits; Farr \& Rossman 2003). Mucoharknessia is distinguished from these genera by lacking the brown, furfuraceous margins around the ostioles of conidiomata, and by being allied to the Botryosphaeriaceae. Finally, the genus Sakireeta is resurrected, and shown to cluster apart from Tiarosporella, having multilocular conidiomata embedded in a brown stroma, which is distinct from the solitary conidiomata of Tiarosporella s.str.

In spite of recent studies that have provided molecular support for 18 genera in the Botryosphaeriaceae (Crous et al. 2013, Phillips et al. 2013, Wijayawardene et al. 2014), the present study adds four new genera to the family, namely Eutiarosporella, Marasasiomyces, Mucoharknessia and Sakireeta. Further studies will undoubtedly discover even more genera and species in this family, which appears to have members that are ecologically diverse, inhabiting grasses as well as woody hosts, with life styles including endophytes, saprobes, plant and human pathogens (Phillips et al. 2013, Slippers et al. 2013). 


\section{Acknowledgements}

Surveys for fungi on Cortaderia selloana in Argentina were funded by "National Biocontrol Collective" and "Future Forests Research," New Zealand. Romina M. Sánchez has a Postdoctoral Fellowship from CONICET. We thank the technical staff, Arien van Iperen (cultures), Marjan Vermaas (photographic plates), and Mieke Starink-Willemse (DNA isolation, amplification and sequencing) for their invaluable assistance.

\section{References}

Carbone, I. \& Kohn, L.M. (1999) A method for designing primer sets for speciation studies in filamentous ascomycetes. Mycologia 91: 553-556. http://dx.doi.org/10.2307/3761358

Crous, P.W., Gams, W., Stalpers, J.A., Robert, V. \& Stegehuis, G. (2004) MycoBank: an online initiative to launch mycology into the 21 st century. Studies in Mycology 50: 19-22.

Crous, P.W., Quaedvlieg, W., Hansen, K. \& Groenewald, J.Z. (2014) Phacidium and Ceuthospora (Phacidiaceae) are congeneric. IMA Fungus 5: 173-193. http://dx.doi.org/10.5598/imafungus.2014.05.02.02

Crous, P.W., Schoch, C.L., Hyde, K.D., Wood, A.R., Gueidan, C., et al. (2009a) Phylogenetic lineages in the Capnodiales. Studies in Mycology 64: 17-47. http://dx.doi.org/10.3114/sim.2009.64.02

Crous, P.W., Slippers, B., Wingfield, M.J., Rheeder, J., Marasas, W.F.O., et al. (2006) Phylogenetic lineages in the Botryosphaeriaceae. Studies in Mycology 55: 235-253. http://dx.doi.org/10.3114/sim.55.1.235

Crous, P.W., Summerell, B.A., Shivas, R.G., Carnegie, A.J. \& Groenewald, J.Z. (2012) A re-appraisal of Harknessia (Diaporthales), and the introduction of Harknessiaceae fam. nov. Persoonia 28: 49-65. http://dx.doi.org/10.3767/003158512X639791

Crous, P.W., Verkley, G.J.M., Groenewald, J.Z. \& Samson, R.A. (eds) (2009b) Fungal Biodiversity. [CBS Laboratory Manual Series 1.] Utrecht: Centraalbureau voor Schimmelcultures.

Crous, P.W., Wingfield, M.J., Guarro, J., Cheewangkoon, R., van der Bank, M., et al. (2013) Fungal Planet description sheets: 154-213. Persoonia 31: 188-296. http://dx.doi.org/10.3767/003158513X675925

Crous, P.W., Wingfield, M.J. \& Park, R.F. (1991) Mycosphaerella nubilosa a synonym of M. molleriana. Mycological Research 95: 628-632. http://dx.doi.org/10.1016/S0953-7562(09)80079-8

Desmazières, J.B.H.J. (1843) Dixième notice sur quelques plantes cryptogames, la plupart inédites, récemment découvertes en France, et que vont paraître en nature dans la collection publiée par l'auteur. Annales des Sciences Naturelles Botanique 19: 335-373.

DiCosmo, F., Nag Raj, T.R. \& Kendrick, W.B. (1984) A revision of the Phacidiaceae and related anamorphs. Mycotaxon 21:1-234.

Farr, D.F. \& Rossman, A.Y. (2003) Dwiroopa, a coelomycetous genus with two 
species. Mycoscience 44: 443-446.

http://dx.doi.org/10.1007/S10267-003-0141-0

Glass, N.L. \& Donaldson, G. (1995). Development of primer sets designed for use with PCR to amplify conserved genes from filamentous ascomycetes. Applied and Environmental Microbiology 61: 1323-1330.

Groenewald, J.Z., Nakashima, C., Nishikawa, J., Shin, H.-D., Park, J.-H., et al. (2013) Species concepts in Cercospora: spotting the weeds among the roses. Studies in Mycology 75: 115-170. http://dx.doi.org/10.3114/sim0012

Höhnel, F. von (1919) Fünfte vorläufige Mitteilung mykologische Ergebnisse (Nr. 300-500). Berichte der Deutschen Botanischen Gesellschaft 37: 153-161.

Hoog, G.S. de \& Gerrits van den Ende, A.H.G. (1998) Molecular diagnostics of clinical strains of filamentous basidiomycetes. Mycoses 41: 183-189. http://dx.doi.org/10.1111/j.1439-0507.1998.tb00321.x

Jami, F., Slippers, B., Wingfield, M.J. \& Gryzenhout, M. (2014) Botryosphaeriaceae species overlap on four unrelated, native South African hosts. Fungal Biology 118: $168-179$. http://dx.doi.org/10.1016/j.funbio.2013.11.007

Jami, F., Slippers, B., Wingfield, M.J. \& Gryzenhout, M. (2012) Five new species of the Botryosphaeriaceae from Acacia karroo in South Africa. Cryptogamie Mycologie 33: 245-266. http://dx.doi.org/10.7872/crym.v33.iss3.2012.245

Karadžić, D.M. (1998) Tiarosporella durmitorensis sp. nov. - a new pathogenic fungus on needles of Abies alba. European Journal of Forest Pathology 28: $145-152$. http://dx.doi.org/10.1111/j.1439-0329.1998.tb01244.x

Lee, S., Groenewald, J.Z. \& Crous, P.W. (2004) Phylogenetic reassessment of the coelomycete genus Harknessia and its teleomorph Wuestneia (Diaporthales), and the introduction of Apoharknessia gen. nov. Studies in Mycology 50: 235252.

Liu, J.K., Phookamsak, R., Doilom, M., Wikee, S., Li, Y.M., et al. (2012). Towards a natural classification of Botryosphaeriales. Fungal Diversity 57: 149-210. http://dx.doi.org/10.1007/s13225-012-0207-4

Minnis, A.M., Kennedy, A.H., Grenier, D.B., Palm, M.E. \& Rossman, A.Y. (2012) Phylogeny and taxonomic revision of the Planistromellaceae including its coelomycetous anamorphs: contributions towards a monograph of the genus Kellermania. Persoonia 29: 11-28. http://dx.doi.org/10.3767/003158512X658766

Müller, M.M. \& Hantula, J. (1998) Diversity of Tiarosporella parca in Finland, Norway and Switzerland. Mycological Research 102: 1163-1168. http://dx.doi.org/10.1017/S095375629800608X

Nag Raj, T.R. (1973) Genera coelomycetum. X. Ellisiella, Samukuta, and Sakireeta. Canadian Journal of Botany 51: 2463-2472. http://dx.doi.org/10.1139/b73-316

Nag Raj, T.R. (1993) Coelomycetous Anamorphs with Appendage-Bearing Conidia. Waterloo, ON: Mycologue Publications.

O’Donnell, K., Kistler, H.C., Cigelnik, E. \& Ploetz, R.C. (1998). Multiple evolutionary origins of the fungus causing Panama disease of banana: concordant evidence from nuclear and mitochondrial gene genealogies. Proceedings of the National Academy of Sciences (USA) 95: 2044-2049. 
http://dx.doi.org/10.1073/pnas.95.5.2044

Phillips, A.J.L., Alves, A., Abdollahzadeh, J., Slippers, B., Wingfield, M.J. et al. (2013) The Botryosphaeriaceae: genera and species known from culture. Studies in Mycology 76: 51-167.

http://dx.doi.org/10.3114/sim0021

Rayner, R.W. (1970) A Mycological Colour Chart. Kew: Commonwealth Mycological Institute.

Roux, C., Coetzee, J. \& van Warmeloo, K.T. (1990) Ontogeny of conidiomata and conidia in Tiarosporella graminis var. karroo. Mycological Research 94: 254 262. http://dx.doi.org/10.1016/S0953-7562(09)80624-2

Sarr, M.P., Ndiaye, M., Groenewald, J.Z. \& Crous, P.W. (2014) Genetic diversity in Macrophomina phaseolina, the causal agent of charcoal rot. Phytopathologia Mediterranea 53: 250-268. http://dx.doi.org/10.14601/Phytopathol_Mediterr-13736

Sieber, T. (1988) Endophytische Pilze in Nadeln von gesunden und geschädigten Fichten (Picea abies [L.] Karsten). European Journal of Forest Pathology 18: 321-342. http://dx.doi.org/10.1111/j.1439-0329.1988.tb00220.x

Slippers, B., Boissin, E., Phillips, A.J.L., Groenewald, J.Z., Lombard, L., et al. (2013) Phylogenetic lineages in the Botryosphaeriales: a systematic and evolutionary framework. Studies in Mycology 76: 31-49. http://dx.doi.org/10.3114/sim0020

Smith, H., Wingfield, M.J., Crous, P.W. \& Coutinho, T.A. (1996) Sphaeropsis sapinea and Botryosphaeria dothidea endophytic in Pinus spp. and Eucalyptus spp. in South Africa. South African Journal of Botany 62: 86-88.

Subramanian, C.V. (1961) On some species of Cryptostictis. Proceedings of the National Institute of Science, India Part B Biological Sciences 27: 236-245.

Subramanian, C.V. \& Ramakrishnan, K. (1957) Neottiospora Desm. and two new genera Samukuta and Sakireeta. Journal of the Indian Botanical Society 36: 68-86.

Sutton, B.C. (1980) The Coelomycetes: Fungi imperfecti with pycnidia, acervuli, and stromata. Commonwealth Mycological Institute, Kew, Surrey.

Sutton, B.C. \& Alcorn, J.L. (1974) Neottiosporina. Australasian Journal of Botany 22: $517-530$. http://dx.doi.org/10.1071/BT9740517

Sutton, B.C. \& Marasas, W.F.O. (1976) Observations on Neottiosporina and Tiarosporella. Transactions of the British Mycological Society 67: 69-76. http://dx.doi.org/10.1016/S0007-1536(76)80009-5

Vilgalys, R. \& Hester, M. (1990) Rapid genetic identification and mapping of enzymatically amplified ribosomal DNA from several Cryptococcus species. Journal of Bacteriology 172: 4238-4246.

White, T.J., Bruns, T., Lee, J. \& Taylor, S.B. (1990) Amplification and direct sequencing of fungal ribosomal RNA genes for phylogenetics. In: Innis MA, Gelfand DH, Sninsky JJ, White TJ (eds), PCR Protocols: a guide to methods and applications: 315-322. San Diego: Academic Press.

Whitney, H.S., Reid, J. \& Pirozynski, K.A. (1975) Some new fungi associated with needle blight of conifers. Canadian Journal of Botany 53: 3051-3063. http://dx.doi.org/10.1139/b75-334 
Wijayawardene, N.N., Crous, P.W., Kirk, P.M., Hawksworth, D.L., Boonmee, S., et al. (2014) Naming and outline of Dothideomycetes - 2014 including proposals for the protection or suppression of generic names. Fungal Diversity 69: 1-55. http://dx.doi.org/10.1007/s13225-014-0309-2

Wikee, S., Lombard, L., Nakashima, C., Motohashi, K., Chukeatirote, E., et al. (2013) A phylogenetic re-evaluation of Phyllosticta (Botryosphaeriales). Studies in Mycology 76: 1-29.

http://dx.doi.org/10.3114/sim0019 